\title{
Shu as a hallowed land: Du Guangting's Record of Marvels
} Franciscus Verellen

\section{Résumé}

L'effondrement des Tangen 907 AC. entraîna la fragmentation de l'empire chinois. Division territoriale et instabilité politique dominèrent jusqu'à la consolidation de l'empire Song dans les années 960 . Pendant cette période des « Cinq dynasties et Seize royaumes ", chaque régime indépendant revendiquait le droit divin de gouverner sa région, quand ce n'était pas l'héritage du mandat du ciel sur l'empire chinois. La legitimation du pouvoir local s'appuya sur l'éventail de présages et de preuves transcendantes élaboré depuis l'antiquité; en même temps, la culture régionale et la mémoire historique des communautés devinrent des atouts pour réclamer l'indépendance. Cette revalorisation des traditions indigènes fut à l'origine du régionalisme en Chine après la réunification. La religion locale joua un rôle primordial dans ce processus. Les origines d'un grand nombre de cultes populaires de la Chine moderne remontent aux cultes locaux patronnés par les pouvoirs régionaux de cette époque. L'œuvre de Du Guangting, taoïste de cour et grand écrivain de la transition Tang-Song, témoigne à maints égards de cette symbiose entre culture religieuse locale et pouvoir politique dans la région du Sichuan (Shu). Son "Récit des merveilles » (Luyi jï), sujet de la présente étude, contribua à la consécration de cette région et de son premier souverain, Wang Jian, en faisant état d'une panoplie de traits distinctifs : la civilisation ancienne de Shu, ses mythes et ses dieux, saints personnages et sites sacrés, géologie et topographie, faune et flore, cultes populaires et curiosités ethnographiques. Sur le plan littéraire, l'ouvrage s'inscrit dans la tradition des mirabilia zhiguai, laquelle visait à l'interprétation du surnaturel et de l'étrange par rapport aux affaires humaines et politiques. Le Sichuan du Xe siècle ressort des pages de ce recueil comme une terre bénie dont les particularismes auraient justifié de longue date son autonomie.

\section{Citer ce document / Cite this document :}

Verellen Franciscus. Shu as a hallowed land: Du Guangting's Record of Marvels. In: Cahiers d'Extrême-Asie, vol. $10,1998$. Culte des sites et culte des saints en Chine. pp. 213-254;

doi : https://doi.org/10.3406/asie.1998.1134

https://www.persee.fr/doc/asie_0766-1177_1998_num_10_1_1134

Fichier pdf généré le 06/02/2019 


\title{
SHU AS A HALLOWED LAND: DU GUANG- TING'S RECORD OF MARVELS
}

\author{
FRANCISCUS VERELLEN
}

\begin{abstract}
L'effondrement des Tang en 907 A.C. entraina la fragmentation de l'empire chinois. Division territoriale et instabilité politique dominèrent jusqu'à la consolidation de l'empire Song dans les années 960. Pendant cette période des "Cinq dynasties et Seize royaumes ", chaque régime indépendant revendiquait le droit divin de gouverner sa région, quand ce n'était pas l'héritage du mandat du ciel sur l'empire chinois. La legitimation du pouvoir local s'appuya sur l'éventail de présages et de preuves transcendantes élaboré depuis l'antiquité; en même temps, la culture régionale et la mémoire historique des communautés devinrent des atouts pour réclamer l'indépendance. Cette revalorisation des traditions indigènes fut à l'origine du régionalisme en Chine après la réunification. La religion locale joua un rôle primordial dans ce processus. Les origines d'un grand nombre de cultes populaires de la Chine moderne remontent aux cultes locaux patronnés par les pouvoirs régionaux de cette époque. L'ouvre de Du Guangting, taoiste de cour et grand écrivain de la transition Tang-Song, témoigne à maints égards de cette symbiose entre culture religieuse locale et pouvoir politique dans la région du Sichuan (Shu). Son "Récit des merveilles" (Luyi ji), sujet de la présente étude, contribua à la consécration de cette région et de son premier souverain, Wang Jian, en faisant état d'une panoplie de traits distinctifs: la civilisation ancienne de Shu, ses mythes et ses dieux, saints personnages et sites sacrés, géologie et topographie, faune et flore, cultes populaires et curiosités ethnographiques. Sur le plan littéraire, l'ouvrage s'inscrit dans la tradition des mirabilia zhiguai, laquelle visait à l'interprétation du surnaturel et de l'étrange par rapport aux affaires humaines et politiques. Le Sichuan $d u X e$ siècle ressort des pages de ce recueil comme une terre bénie dont les particularismes auraient justifié de longue date son autonomie.
\end{abstract}

After the collapse of the Tang dynasty in AD 907, the worst-case political scenario in the eyes of many ordinary Chinese and their leaders since the foundation of the empire came true: its fragmentation into separate and independent regimes. The loss of China's territorial integrity, accompanied by civil war and social turmoil, meant the end or suspension of sovereignty itself, conceived as the rule of the unique Son of Heaven over "all under Heaven."

Despite apprehensions about the territorial division and political instability that prevailed until the reunification of the empire in the latter part of the tenth century, regional regimes nevertheless successfully established and maintained their independence. Their separate claims to dynastic legitimacy had, moreover, the effect of boosting a new sense of local community. After the destruction of the Tang capital Chang'an in the 880 s, the usual attraction of local talent to the center was also temporarily reversed.

Cahiers d'Extrême-Asie 10 (1998): 213-254 
Refugees from the ruined metropolis, including members of the former class of Tang literati-officials, played an important part in furnishing independent regimes with their instruments of sovereignty. Beside the established rhetoric and symbolism of dynastic legitimation based on the "mandate of Heaven," historical and cultural claims to territorial integrity and local community were advanced as titles to autonomy. As a result, distinctive legacies of the regions under the control of local kingdoms were rediscovered and promoted.

According to the theory of Benedict Anderson, assumptions about a community's defining characteristics, shared by its numerous and anonymous members, can be interpreted as the product of cultural projections. Although Anderson seeks primarily to explain the incorporation of communities as nations and the formation of nationalist ideologies, the model can be applied, mutatis mutandis, to the precursors of the modern nation-state and nationalism as well. The dynastic realm, ruled by divine dispensation, derived its legitimacy from beliefs in the sacrality of the king's person and authority, and from imaginative acts of cultural identification both among subjects and between subject and ruler. ${ }^{1}$

During much of the tenth century, the south-western part of China corresponding to modern Sichuan province was ruled by two successive regimes known retrospectively as the Former and the Later Shu. The name of Shu 蜀 evoked the ancient ethnic and cultural descent of the majority of the inhabitants of this region on the periphery of Han civilization. It also recalled their intermittent history of political autonomy. From the declining years of the Tang onward, the writings of contemporary religious, literary, and political figures reflect a heightened consciousness of the region's cultural identity, its cosmological singularity as the cradle of Heavenly Master Taoism in the second century $\mathrm{AD}$, and the historical precedents for independence. Though it is difficult to gauge the diffusion of ideas propagated by tenth-century literati writings, their role in the process of building communal identities was in some ways analogous to that of the printing press in the rise of modern nationalism. ${ }^{2}$

The early tenth-century Record of Marvels, Luyi ji 錄異記, is a case in point. By representing Shu as a distinctive and supernaturally endowed realm, this work reinforced at a critical moment a sense of community in the region and lent authority to the imperial aspirations of its leaders. The present study examines selected items from the Luyi ji, in the form of translations and synopses, with a view to assessing the book's contribution, in religious, political, or cultural terms, to the consecration of the Former Shu kingdom and its ruling house in the early tenth century.

\section{THE RECORD OF MARVELS}

The Record of Marvels is the work of Du Guangting 杜光庭 (850-933), a court Taoist

1 Benedict Anderson, Imagined communities: Reflections on the origin and spread of nationalism, revised edition, London: Verso, 1991. For discontinuities between the two types of political communities, see ibid., 19-22.

2 Cf. Imagined communities, 37-46. 
in the service first of the Tang dynasty and, subsequently, of the Shu kingdom. ${ }^{3}$ The collection, originally comprising ten juan, ${ }^{4}$ was presented to Wang Yan 王衍 (898-925), the second ruler of Shu, sometime between the spring of 921 and the demise of the Former Shu in the year $925 .^{5}$ Although not ostensibly a book about Shu, about half of its narratives are directly or indirectly concerned with the cultural, religious and political heritage of the region and the legitimacy of its ruling house. ${ }^{6}$ The term luyi 錄 異 in the title, "recording the marvelous," echoes the generic name zhiguai 志怪, "recording the extraordinary," of Chinese medieval mirabilia literature. " The author's preface clearly places the work's politico-religious agenda within the literary and philosophic purview of that tradition. This can be seen from his subscription to certain theoretical conventions of zhiguai-writing, exemplified by the three main propositions advanced in the preface: 8

1. The opening apology for displaying an interest in the supernatural, in spite of the reticence in that regard ascribed to the "sage," i.e. Confucius. 9 In truth, says $\mathrm{Du}$, discussions of prodigies are found everywhere in the [Confucian] classics themselves, in official historiography, as well as the orthodox divinatory writings.

2. The argument of the book's derivation: As precursors to his work, the author lists three classics of the zhiguai tradition, the Shuyi ji 述異記, the Powu zhi

3 See Franciscus Verellen, Du Guangting (850-933): Taoiste de cour à la fin de la Chine médiéval, Paris: Collège de France, 1989.

4 See Chongwen zongmu 崇文總月 (1042) 6.3b, in Yingyin Wenyuan ge siku quanshu 招印文

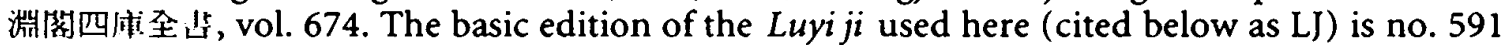
in the concordance of titles by Kristofer Schipper, in fascicle 327 of the Zhengtong Daozan 正 統道藏 (D 327, no. 591). Several other Ming versions survive, manuscripts as well as printed editions, including a useful edition in the collection Bice huihan 秘冊楥的 1603 . The most complete extant versions are in eight juan.

5 The latest internal date is 26 February 921 (in the story "Yanyang dong 焰陽洞，"L) $6.7 \mathrm{~b}-9 \mathrm{a}$ ). The book's political message implies a presentation before the fall of the kingdom.

${ }^{6}$ My list of items fitting this description contains between 70 and 80 titles, out of a total of 162 , including some items not directly concerned with Shu but lending weight to stories about the legitimation of its regime by adducing antecedents and parallels elsewhere, notably from the Tang imperial court.

7 On zhiguai, see Li Jianguo 李劍國, Tang qian zhiguai xiaoshuo shi 唐前志怪小説史, Tiantsin: Nankai daxue, 1984, and Robert Campany, Strange Writing: Anomaly Accounts in early medieval China, Albany: State University of New York Press, 1996.

8 For a full translation and annotation of the preface, see Verellen, Du Guangting, 174-76. See also the discussion of a similar preface from the mid-Tang in Glen Dudbridge, Religious experience and lay society in T'ang China: A reading of Tai Fu's Kuang-i chi, chapter 2, Cambridge: Cambridge University Press, 1995.

${ }^{9}$ Quoting Lunyu 論語 7, “The sage would not discuss prodigies, feats of strength, disorders, and spirits." 
博物誌, and the Yiwen ji 異聞集 ${ }^{10}$ as “all belonging to the same genre 皆其流也.”

3. Substantiation of point one above by adducing numerous "incidences of the divine transformations between Yin and Yang," i.e. metamorphoses and other unusual occurrences in nature and in human society that appear to be abnormal yet are based on the laws of transformation. The examples are drawn from canonical literature and "talismanic writings which portend good and evil fortune." Such phenomena "come into being through the work of the two vital energies 二氣 (i.e. Yin and Yang), and make their appearance in accordance with the Five Phases 五行...: They appear when it is their lot and then inevitably manifest themselves; and they dissolve when their ordained period is up, and then must inevitably disappear. ${ }^{11}$

The proposition that irregularities in nature and society were in fact the work of natural law and charged with significance as documented by precedents in recorded history, is at the nexus of mirabilia writing and historiography in China. The work of both the recorder of mirabilia and the official historiographer was of an essentially mantic nature. While the implications of this transcendent world of fleeting boundaries also interested Tang writers of fiction and hagiography, ${ }^{12}$ for Du Guangting "discussing prodigies, feats of strength, disorders, and spirits" belonged to the official business of a court Taoist. In this he continued the religious and political traditions of the Han masters of arcana 方士. Their cosmological and political designs had found expression in another kind of writing closely connected with dynastic legitimation, the apocryphal commentaries to which Du Guangting's preface refers also. ${ }^{13}$

The Record of Marvels claimed in effect a cosmological sanction for the succession of the rulers of Shu to the Tang dynasty, while pointing to historical precedents for the region's political independence. As a work of literature, it encouraged a sense of cultural cohesion by drawing together the most divers elements of indigenous tradition in Shu, ranging from supernatural manifestations connected with numinous sites and saintly people, mythology and ancient history, to ethnography and the wonders of the region's natural geography: the famous mountains, streams, and grottoes of Shu, strange geological formations, the peculiar properties of its fauna. The structure of the

10 By Ren Fang 任㕫 (460-508), attributed to Zhang Hua 張萨 (232-300), and by Chen Han 陳翰 (fl. 874), respectively.

$11 \mathrm{Cf}$. the phrase in Liezi 列子 1, “The born cannot escape birth, the changing cannot escape change; therefore birth and change are the norm."

12 See Glen Dudbridge, The tale of Li Wa: Study and critical edition of a Chinese story from the ninth century, 63, London: Ithaca Press, 1983, and F. Verellen, "Encounter as revelation: A Taoist hagiographic theme in medieval China," forthcoming in Bulletin de l'Ecole Française d'Extrême-Orient 85 (1998).

13 On this subject, see Anna Seidel, "Imperial treasures and Taoist sacraments: Taoist roots in the apocrypha," in Tantric and Taoist studies in honour of R.A. Stein, edited by M. Strickmann, 2: 291-371, Brussels: Institut Belge des Hautes Etudes Chinoises, 1983. 
book is encyclopedic and foreshadows, albeit on a much smaller scale and in imperfectly preserved form, the cosmological arrangement of the five hundred-juan imperial anthology Taiping guangji 太平廣記, compiled half a century later:

Table of contents of the Record of Marvels

Juan 1: “Immortals 仙”

Juan 2: “Extraordinary men 異人”

Juan 3: a. “Loyalty 忠”

b. "Filial devotion 孝"

c. "Marvelous responses 感應”

d. “Marvelous dreams 異夢”

Juan 4: “Demons and spirits 鬼神”

Juan 5: a. "Dragons 龍”

b. “Supernatural tigers 異虎”

c. “Supernatural tortoises 異龜”

d. “Supernatural softshell turtles 異㸗”

e. “Supernatural snakes 異蛇”

f. “Supernatural fishes 異魚”

Juan 6: “Grottoes 洞”

Juan 7: a. “Supernatural waters 異水”

b. “Supernatural stones 異石”

Juan 8: “Tombs 墓"

With one or two exceptions, all of these categories also feature, in similar hierarchical order, in the Taiping guangji ${ }^{14}$ which reproduces more than half of the extant contents of the Record of Marvels. ${ }^{15}$ Twenty-four of the stories from the Luyi ji thus anthologized are uniquely preserved in the Taiping guangji-filling in large part the gap left by the two missing juan of the original Record. ${ }^{16} \mathrm{~A}$ few of these lost stories recuperated

14 See Taiping guangji 太平廣記 (987), Peking: Zhonghua shuju, 1981 edition (TP below); Edward H. Schafer, "The table of contents of the T'ai-p'ing kuang-chi," CLEAR 2 (1980): 258-63.

15 I.e., 85 out of 162 stories. See the references in Zhou Ciji 周次吉, Taiping guangji renming shuming suoyin 太平廣記人名書名索引, “Shuming 書名," 56, Taipei: Yiwen yinshu guan, 1973.

16 Extrapolating from the number of stories extant in the current eight-juan editions (138), this supplement from Taiping guangii raises the proportion of surviving text to $94 \%$. Useful synoptic versions of the Luyi ji include Leishuo 類説 (1136) 8.24b-27b, Peking: Wenxue guji, 1955 edition (six stories) and Shuofu 説郛 (120 j., 14th c. with 17th c. revisions) 
via Taiping guangji fit obviously under existing chapter headings in the eight-juan edition; ${ }^{17}$ the remainder give an indication of the categories that must have been covered by the lost chapters: "Good omens on behalf of monarchs 帝王休徵,"18 “Curios 器玩;"19 “Illusionists 幻術" 20 “Thunder 雷;"21 “Mountain streams 山溪;"22 “Rodents 鼠;"23 “Deer 鹿;"24 “Birds 禽鳥;"25 “Watery tribes 水族;" 26 and “Insects 昆 蟲."27

For the purposes of the present study, the narratives from the Luyi ji selected here as broadly concerned with aspects of the cultural and sacred history of Shu, will be grouped according to the following themes: 1 . Gods, saints, and immortals; 2 . Sacred sites and natural history; and 3. The mandate of Shu.

118.1a-6a, in Shuofu sanzhong 説郛三種, Shanghai: Shanghai guji chuban she, 1988 (sixteen stories). Neither of these features additional items to those found in LJ and TG. The narratives in LJ are untitled; in a few instances, related items linked together under a single paragraph are treated here as separate narratives. The titles below, taken from TG versions when available, are supplied for convenient reference.

17 “Huang Wanyou 黃萬祐” (TG 86.558), in the Taiping guangji section entitled Yiren 異人 (corresponding to LJ 2); “Peishi zi 裴氏子" (TG 311.2465), section on Shen 神 (LJ 4); “Han Zhong 韓種” (TG 316.2498-99), Gui 鬼 (LJ 4); and “Yingling 營陵” (TG 472.3886), Gui 龜 (cf. LJ 5.c and d).

18 “Jin woniu 金蝸牛” (TG 135.972). Generally, these were natural portents produced by animals, plants, or minerals: here a snail displays the characters "Son of Heaven 天子" in the reign of Tang Xuanzong (712-756). Stories of this kind are present in the surviving eight-juan version of the Luyi ji, but classed differently (e.g. under 5.c "Supernatural tortoises").

19 “Zhou Han 周邯” (TG 232.1779). The attribution of this story is doubtful. Taiping guangji elsewhere (422.3435-36) ascribes a more elaborate version to the Chuanqi 傳奇 of Du's older contemporary Pei Xing 裴鋓 (825-880). See also the comments in the reconstruction Pei Xing chuanqi 裴鉜傳奇, edited by Zhou Lengqie 周楞伽, 35, Shanghai: Shanghai guji chuban she, 1980 . The present version cites alternatively another Tang work, the Yuanhua ji 原化記, by Mr. Huangfu 皇甫氏.

20 “Hou Ziguang 侯子光” (TG 284.2267).

21 “Zhang Quan jie 漳泉界” (TG 393.3139-40); “Xu Chan 徐誗” (TG 393.3144); and the continuation “idem 又" of the story entitled “Xu Zhitong 徐智通” (TG 394.3149).

22 “Xidu 湑毒” (TG 397.3183).

23 “Gongshu 拱鼠” (TG 440.3585); “Yanshu 鼠鼠” (TG 440.3585-86); “Yishu 義鼠" (TG 440.3586); and "Boshu 白鼠" (TG 440.3586).

24 “Lu ma 鹿馬” (TG 443.3622).

25 “Daisheng 戴勝” (TG 463.3814-15) and “Xianju shan yiwu 仙居山異鳥” (TG 463.3815).

26 “Lutang 盛塘” (TG 469.3864). This story, about metamorphoses of jiaoyu 鮫魚 “sharks” into women and men, might have figured among the strange fishes in LJ 5.f. For the jiaomyth, see Edward Schafer, "A vision of shark people," Schafer Sinological Papers 35, Berkeley 1989 (unpublished).

27 “Shashi 沙闽”(TG 478.3935); “Shuinu 水驽”(TG 478.3936); “Bishi 壁螼”(TG 479.3943-44); “Bochong 白蟲” (TG 479.3944); and “Shedu 舍毒” (TG 479.3946). 


\section{GODS, SAINTS, AND IMMORTALS}

References to the region's cultural origins in the Luyi ji include stories concerning the founding myths of the "Shu-Ba 蜀巴" peoples, in particular of the tribes of the Ba region in Eastern Sichuan. The Record thus features a version of the famous myth of the elevation of the $\mathrm{Ba}$ clan to local supremacy under their first leader, the Lord of the Granary, Lin jun 离君: ${ }^{28}$

In ancient times, two stone caves appeared after a landslide at Mt. Wuluo Zhongli 武落鐘籬山 (in modern Changyang county, Hubei, the ancient home of the Ba people). One was black, the other red. From the red cave emerged a man named Wuxiang 務相. His surname was $\mathrm{Ba}$ 巴. Out of the black cave came four clans named Hao 蚯, Fan 樊, Po 柏, and Zheng 鄭. The five clan heads (lit., "surnames") fought each other for supremacy 長. ${ }^{29}$ Then they agreed that he who could pierce the [wall of the] cave with his sword would be Lord of Lin (Lin jun 床君). ${ }^{30}$ None but Wuxiang succeeded whose sword remained lodged [in the wall of the cave]. Then they made boats of clay 土 and declared that he who could float his boat would be Lord of Lin. Again, only Wuxiang's boat floated, and thus he was proclaimed Lord of Lin.

Wuxiang then embarked on his boat and with his foot soldiers descended the river Yi 夷水. ${ }^{31}$ When they reached Yanyang 監陽, the water goddess of Yanyang stopped the Lord of Lin, saying: "This place is rich in fish and salt, and the territory is vast. We shall live together here. You should stop here and proceed no further." The Lord of Lin said: "I am bound to be Lord of Lin and to seek my territory; I may not stop here." At night the Spirit of the Yan 監神 followed the Lord of Lin to his sleeping place. In the morning she became a flying insect, and as all the spirits followed her, their flight concealed the sun. The Lord of Lin wanted to kill them but was unable to make them out, nor could he distinguish Heaven from Earth or East from West. This continued for ten days. The Lord of Lin then bestowed a blue thread 青縷 on the spirit of Yan, saying: "Wear this as a sign of consent, and I shall live with you; if you do not consent, I shall leave you." The Spirit of Yan accepted and wore it. Standing on a rock on the Yang-side (i.e., the north bank of the riv-

28 LJ 2.1a-2a; ap. TP 481.3963-64. The version here is transcribed from Jin shu 晉書, compiled by Fang Xuanling 方玄齡 (578-648) et al., 120.3021-22; see also the earlier and more concise version in Hou Han shu 後漢書 (5th c.) 86.2840-41 (references to dynastic histories are to the Zhonghua shuju editions). For the different versions of the Lin jun story, see also Terry Kleeman, Great Perfection: Religion and ethnicity in a Chinese millennial kingdom, 117-19, Honolulu: University of Hawaii Press, 1998.

29 Jin shu has "divinity 神."

30 I.e., head of the Southern Man tribes; see Hou Han shu, ibid.

31 I.e., the Qing River 清水 in southwestern Hubei; cf. Steven F. Sage, Ancient Sichuan and the unification of China, 51, Albany: State University of New York Press, 1992. 
er), ${ }^{32}$ the Lord of Lin could recognize the one wearing the blue thread on her chest from afar. He knelt and, letting fly an arrow from his bow, struck the Spirit of Yan. When the Spirit of Yan was dead, all the other spirits who had flown with her departed and the sky cleared. The Lord of Lin again embarked his clay boat and continued to Yicheng 夷城. ${ }^{33}$ At Yicheng, the water from the source followed a bend in the stone cliff creating the appearance of a cave. When the Lord of Lin beheld this, he sighed and said: "Having just emerged from a cave, must I now enter this?" Thereupon, the embankment collapsed over a width of thirty feet, forming a series of steps. The Lord of Lin ascended these. On top of the embankment there was a flat rock, five by ten feet. There he halted. By divination and calculation he confirmed the site. Thus he built his city beside the rock and lived there, and his tribe multiplied. When the Qin had unified the empire, they made this [territory] into Qianzhong commandery 黔中郡 and levied a tribute of $400.000^{34}$ cash annually. The people of $\mathrm{Ba}$ called this tribute “cong 宾." Therefore they are known as "Cong-people."

The multiple themes of the Lin jun myth-defeat of the water goddess, the importance of salt as a regional natural resource, the transition to sedentary agriculture inaugurated by the Lord of the Granary, the gathering and prospering of an hitherto dispersed people-reverberate throughout the cultural history of early Sichuan, linking Lin jun with such heroes as Li Bing 李冰, the Qin hydraulic engineer, and Zhang Daoling 張道陵, the founder of Heavenly Master Taoism. ${ }^{35}$ The final reference to the integration of the region into the Chincsc cmpire evokes the problem of Han-ethnic relations, a recurring theme in the Luyi ji. Du returns to the mythical ancestry of $\mathrm{Ba}$ in the form of legends concerning the White Tiger, the incarnation of the Lord of Lin's soul after his death, ${ }^{36}$ totem of the Ba people, and emblematic animal of the West.

The first story in the Luyi ji touching on this subject highlights the tension between the Ba people's worship of the White Tiger and attempts on the part of their Han civilizers to eradicate the "barbaric" cult. The tale of Kuo Pu 廓浦 begins with the appointment of magistrate Sun 孫令 to Yongqing county 永青縣, Fangzhou 房州 (modern Zhushan, Hubei) in $820-824 .{ }^{37}$ A forgotten local deity, identified by a county

32 On the emendation yang 陽 for dang 偒, see Jin shu 120.3032 .

33 Identified as the site of modern Enshi 恩施 in Hubei; cf. Sage, Ancient Sichuan, ibid.

34 Jin shu has "40."

35 See F. Verellen, "Zhang Ling and the Lingjing salt well," in En suivant la voie royale: Mélanges en hommage à Léon Vandermeersch, edited by Jacques Gernet and Marc Kalinowski, 260-65, Paris: Ecole Française d'Extrême-Orient, 1997.

3*i See Hou Han shu 86.2840.

37 LJ 4.6a-7b; ap. TG 307.2431-32. The latter version also cites the similarly titled Jiyi ji 集 異記 by magistrate Sun's contemporary Xue Yongruo 薛用弱 (fl. 821-824), listed in Xin Tang shu 新唐書 59.1541 as having 3 juan. Modern versions, in 1 juan, do not contain this story (see Yingyin Wenyuan ge siku quanshu, vol. 1042, and Boyi zhi, Jiyi ji 博異志, 集異記, edited by Jin 
clerk as "the prince of Yongqing," oppresses Sun and his brother with melancholy, then finally appears to them to tell his story: Named Kuo $\mathrm{Pu}$, he was a descendant of $\mathrm{Zhou}$ Chu 周處 (242-297), ${ }^{38}$ a famous slayer of tigers, and had himself rid Xicheng commandery 西城郡 (Ankang, southern Shaanxi) of an extraordinary specimen, the chief of man-eating tigers: "Of awe-inspiring appearance, he was uncommonly powerful and swift. His body was like white brocade, and on his forehead a round mirror flashed brilliantly. He had brought countless people to grief."

Xicheng was the site of an important temple dedicated to the White Tiger, the Bohu shen miao 白虎神廟. The legend of Zhang Daoling, presenting him as a civilizing hero of the region, speaks of Zhang's move into the Xicheng shan 西城山 area where he built an altar to worship the Perfected 朝真 and invoke the Five Emperors 五帝. “A villager told him that in the Fangling 房陵 region in Xicheng there was a White Tiger Spirit 白 虎神 that was fond of drinking human blood. Every year the local people killed a person as a sacrifice to him. [Zhang Daoling] summoned this spirit and reprimanded it. Thereupon [its ravages] ceased."39

To return to Kuo Pu: The local people, moved to gratitude for his elimination of the White Tiger scourge, erected numerous temples for him: "From north of Xianghan 襄漢 and south of Languan 藍關 my likeness and shrines are found in over thirty places. And this temple is my resting place. In the course of many years popular tradition 俗傳 has generally fallen into error by assuming that my ancestral temple is the Spirit of the White Tiger temple (i.e., the Bohu shen miao 白虎神廟 in Xicheng). This is totally mistaken. Fortunately, you sir have made enquiries and obtained the full story. I wish you to make it widely known in order to rectify the error." The remainder of the narrative is dedicated to documenting this rectification by reference to a stele inscription from the mid-ninth century, itself based on a weathered wooden panel inscribed on the initiative of magistrate Sun and his brother. The stele inscription, by the executive officer inspecting local customs 觀風判官 in Xiangzhou 襄州 prefecture (Xiangyang, Hubei), Wang Shicheng 王士澄, interestingly couches the import of the god's revelation in terms of establishing the distinction between "ritually perverse and correct 邪 正."40

The tension between the popular cult of the White Tiger on the one hand, with its echoes of primitive totem worship among the $\mathrm{Ba}$, and the attempts of Chinese colonizers and Taoists to eradicate what they regarded as savage blood sacrifices on the other, found significant expression in the issue of taxation, as suggested at the end of

Wenming 金文明, Hangzhou: Zhejiang guji chuban she, 1984. Gu Tianhong 古添洪, “Jiyi ji

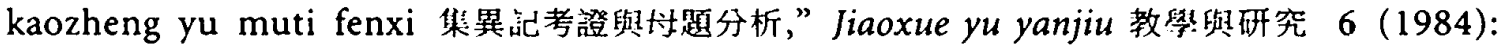
229-58, lists a total of 80 attributions to the Jiyi ji in TG, including the present story (p. 253).

38 See Jin shu 58.1569.

39 See Lishi zhenxian tidao tongjian 歴史真仙體道通鑑 (preface 1294), by Zhao Daoyi 趙道 一, 18.4a, D 139-48, no. 296.

40) See the comments on the shorter TG version of this story, which omits the citation of the stele inscription, in David Johnson, "The city god cults of T'ang and Sung China," Harvard Journal of Asiatic Studies 45 (1985): 432-33. 
the Lin jun story above. The earliest surviving regional history of Shu, the fourth-century Huayang guo zhi 華陽國志, reports a tax exemption granted the Ba by the Qin in the early third century $\mathrm{BC}$ as a reward for having killed a hitherto invincible tiger, i.e. their own ancestral god. As in other colonial contexts, the imposition of taxes on the "primitive" peoples inhabiting the periphery of civilization, the Roman tributum, was a perfect measure of their submission and assimilation. ${ }^{41}$

Under the heading "Supernatural Tigers 異虎” is found the story of Aunt Eighteen, Shiba yi 十八姨, ${ }^{42}$ a tiger spirit who patrolled the region of Jianzhou 劍州 along the Jialing 嘉陵 river, punishing evildoers, while, in the guise of a "human transformation," exhorting the population to do good. In another story linking the tiger to retribution, a young woman is transformed into a tiger as a punishment for stealing temple property. Forced to leave her family and human society, she eventually disappears, still wearing bracelets on her paw. ${ }^{43}$

"Magistrate Cui 崔令"44 is another detailed and instructive study of the ubiquitous conflict between local officialdom and popular cults. The places mentioned in this story are situated in the area of modern Hechuan 合川, another ancient Ba territory on the confluence of the Fujiang 涪江 and the Jialing jiang 嘉陵江 rivers, fifty km northwest of modern Chongqing:

After the official residence in Bachuan county 巴川縣, Hezhou 合州, had been destroyed as a result of armed conflict 兵亂, ${ }^{45}$ it was moved into a stockaded compound where [its inhabitants] were better able to protect themselves. At the time when magistrate Cui was in office, ${ }^{46}$ an able-bodied soldier 健卒 came to pillage the wood of the stockade. He was captured and sent to the garrison where the garrison commander had him executed.

The soldier's family formerly ${ }^{47}$ worshipped the god of Bishan 壁山神. ${ }^{48}$ Following the death of the soldier, therefore, the god haunted 崇 the magistrate's household. He would manifest himself coming and going, heap abuse on them out of the void, throw burning torches and break utensils. Money, silk [currency], and

41 See Huayang guozhi (ca. 347), by Chang Qu 常壉, edited by Ren Naiqiang 任乃強, Huayang guo zhi jiaobu tuzhu 萑晹國志校補阔注, 1.14, Shanghai: Guji chuban she, 1987, and Kleeman, Great Perfection, 39-41.

42 LJ 5.3a-b; ap. TG 433.3514. On the name "Shiba yi," see Qian Zhongshu 錢鍾甼, Guanzhui bian 管錐編 2: 813, Peking: Zhonghua, 1979.

43 LJ 5.3b; ap. TG 431.3498. See also Charles E. Hammond, "An excursion in tiger lore," Asia Major 3rd ser. 4.1 (1991): 87-100.

44 LJ 4.7b-9a; ap. TG 352.2790.

4.5 TG var. "uprising."

46 TG: "A certain Cui was magistrate."

47 Literally, “originally 元." TG var: 先.

48 Bishan county was situated to the northwest of Ba county. The author declares below that the identity of this god was unknown. 
clothes would inexplicably disappear. Many of the clothes inside trunks kept under lock were found shredded. ${ }^{49}$ [The household] took recourse to magic and propitiation, but neither was able to bring [the disturbances] under control. The magistrate resigned his office and returned home, a distance of one thousand $l i$ away. The specter 崇 followed him. Moreover, day and night he ate and drank like a human being. The entire family waited on him and dared not be neglectful. The expenses were so great that they caused them much hardship.

Suddenly one morning, the whole family heard the sound of a great bird beating its wings as it descended above the house. After a while, a loud voice was heard from the air: "I have come." Old and young, the entire household paid reverence to him. Titling himself "great prince 大王," the specter [no. 2] said: "That you all suffer misfortune is because you have run into my brother Yongxi 䔨 溪 who has unreasonably destroyed your livelihood, caused the loss of your property, and played every supernatural trick on you. To be sure, you fear him greatly! As of now he is dispatched for good. Your misfortunes are over and your good fortune is on the rise. The great prince has come in person ${ }^{50}$ to sojourn here for a while. I shall temporarily borrow the Tianpeng 天 ${ }{ }^{51}{ }^{51}$ niche to install myself. This version of the Tianpeng [spell] is excellent. ${ }^{52}$ I shall borrow it to make a copy up in Heaven for passing it on. I'll bring it round in three to five days." A few days later, the Tianpeng has been stuck to a high place on the eaves of the residence. It was neither dirtied nor damaged. ${ }^{53}$ From then on, [specter no. 2] stayed day and night...

The narrative goes on to describe the behavior of the apparition and his relationship with his hapless entourage: He often summons the master of the house to converse with him, and orders young and old to recite poetry and chant to his tune, correcting every mistake. His discourse tends to exhort people to do good. He also instructs them to practice breathing techniques and to cultivate the Way. Once he declares: "I usually mount on a crane for my comings and goings up in Heaven." On another occasion, he refers to himself by the surname Zhang 張. Every day he eats and drinks like a human

49 On poltergeist phenomena associated with cults, cf. Glen Dudbridge, "Yü-ch'ih Chiung at An-yang: An eighth-century cult and its myths," Asia Major 3rd ser. 3.1 (1990): 27-49; F. Verellen, "Luo Gongyuan: culte et légende d'un saint taoïste," Journal Asiatique 275 (1987): 289-91, 319-22.

50 TG var. "I have come."

51 The demon commander of heavenly hosts and also an ancient exorcistic spell. See Liu Zhiwan 劉知萬, “Tempōshin to Tempōju ni tsuite 天蓬神と天蓬咒について," in Dōkyō to shūkyō bunka 道教と宗教文化, edited by Akizuki Kan'ei 秋月觀暎, 403-24, Tokyo: Hirakawa, 1987.

52 The niche apparently housed a copy of the spell, the Tianpeng zhou 天蓬咒. The following suggests that the object was a sheet of paper.

53 TG abridges this to "affixed the Tianpeng to the eaves of the residence." 
being. ${ }^{54} \mathrm{He}$ also has a daughter, by the name of Miss Jinxiu 錦繡娘, as well as a wife and servants. The outlay for their food is also far from negligible. Generally, on seeing good persons or gentlemen, he willingly speaks. When wicked or violent persons approach, however, he remains silent. Once a drunken monk and a couple of soldiers come to see him. Because their speech is immodest and offensive, he refuses to speak with them. After the monk has left, he gravely announces: "This monk eats dog meat and drinks wine. He is an unprincipled ruffian, and I did not wish to converse with him." As for the conduct of men, their good and bad fortunes and auspicious or adverse circumstances, he knows everything about them and his words never miss the mark. Down to childhood names and seniority rank he is familiar with their particulars. "It is not known which deity he was 未知是何神也."

It should be clear from the above examples that the term "popular" in this context refers to religious practices or beliefs that did not boast an explicit stamp of approval. Although Chinese scholar-officials applied unflattering adjectives to such cults, ranging from "vulgar" and "benighted" to "perverse," they were rarely fundamentally different from their approved counterparts. The issue of blood sacrifices was a bone of contention primarily for Taoists, and a negotiable one at that; officially sponsored cults tended to be as "savage" in this regard as perverse cults. Indeed, the situation on the ground eloquently confirmed Du Guangting's apology in the preface to the Luyi ji (point one above): While the Confucian gentleman professed reticence with respect to the supra-normal world, the facts spoke for themselves.

Frequently, the issue of approval was a matter of strategic alliances between the ruling establishment and potential grassroots supporters, with noticeable shifts taking place in times of dynastic crisis. ${ }^{55} \mathrm{Du}$ Guangting's interest in what we might call the cultural anthropology of popular religion stemmed in part no doubt from his own official preoccupations: As a court Taoist, it was incumbent upon him to classify cults and position them in relation to Taoism and the imperial cult system, first of the Tang dynasty and later of the emerging leadership of independent Shu. The following story, about the Nine Heavens spirit envoy of Lushan 鹰山九天使者, ${ }^{56}$ reflects this concern:

Synopsis: In the Kaiyuan period (713-742), emperor Xuanzong receives in a dream the visit of the Nine Heavens spirit envoy of Lushan, referring to himself as Nine Heavens inspector 採訪, and announcing his wish to build a palace on Mt. Lushan. The deity magically produces all the building materials for the temple, but asks the emperor for construction help. The work is speedily completed. In an

54 True Taoist deities, as opposed to demons, did not eat. Cf. the story about emperor Xuanzong's small tortoise, LJ 5.4a-5a and below.

$55 \mathrm{Cf}$. F. Verellen, "Liturgy and sovereignty: The role of Taoist ritual in the foundation of the Shu kingdom (906-925)," Asia Major 3rd ser. 2.1 (1989): 59-78.

56 LJ 1.2a-3b; ap. TG 29.187-88. On the cult of this deity, see Florian Reiter, "The 'Investigation Commissioner of the Nine Heavens' and the beginning of his cult in Northern Chiang-hsi in 731 A.D.," Oriens 31 (1988): 266-89. 
aside, the author remarks that the resultant temple, its statues, and paintings survived "to this day," i.e. the early tenth century. Xuanzong summons the Tiantai master of instructions Sima Chengzhen 司馬承禎 (647-735) to enquire into the matter. The latter's memorial in response explains the official pantheon with respect to the principal mountain cults: Seeing that mountain and river spirits had been endowed with harmful power through offerings of blood sacrifices, the Most High (Lord Lao) ordered the Superior Perfected 上真 to supervise the rivers and peaks. Thus the Five Sacred Peaks have Perfected Lords 真君 amongst whom the Elder of Qingcheng 青城文人 (Ning Fengzi 甯封子) is chief. The Nine Heavens director of destiny of Qianshan 潛山九天司命 is responsible for the Nine Heavens Life Register 九天生籍, and the Nine Heavens spirit envoy of Lushan controls the records of the Three Heavens and directs public prosecution among the ten thousand spirits. They all serve as Five Peaks supreme officers. Temples should be erected for each of them and sacrifices presented in the form of $z h a i$ 齋-retreats and food offerings. Xuanzong followed this advice (TG) and in the following year temples were built on the Five Peaks and Three Mountains (i.e., Qingcheng, Qianshan, and Lushan).

The information that the Elder of Qingcheng shan, the ancient Taoist site and holy mountain near Chengdu, occupied the highest rank among the mountain gods, including the Five Sacred Peaks of China, was clearly welcome news to the promoters of Shu as a hallowed land. As early as 881 , the year of emperor Xizong's exile to Shu, we find the author of the above presiding over liturgical procedures for a further enfeoffment of Ning Fengzi at the behest of Xizong. ${ }^{57}$

An important area in which the interests of popular cults and local administrations intersected was water control. The Chengdu plain, one of the most productive regions in China, famous for its intensive rice cultivation and intricate, ancient irrigation system, was also the home of numerous, and sometimes competing rain cults. I have described elsewhere the ultimately unsuccessful attempt during the ninth and tenth centuries by followers of the immortal Luo Gongyuan 羅公遠 to supplant the early cult of Li Bing as controller of irrigation, rain, and drought in the Chengdu plain. ${ }^{58}$ By means of an influential piece of hagiographic speculation, the Record of Marvels contributed to this process: Du here first proposes the identification of a successful rain magician named Perfected Luo 羅真人, commemorated in a stele inscription at Ezhou 鄂州 (modern Wuchang, Hubei), with the court Taoist Luo Gongyuan in the reign of emperor Xuanzong (712-756), and finally with the saint of a peasant cult in Sichuan. ${ }^{50}$

57 See Verellen, "Liturgy and sovereignty," 61-62.

58 F. Verellen, "Luo Gongyuan: culte et légende d'un saint taoïste," Journal Asiatique 275 (1987): 283-332.

59 LJ 1.3b-4a; see "Luo Gongyuan," 301-303. Du Guangting gives a vivid ethnographic description of the rise of the Sichuan cult in Daojiao lingyan ji 道教露験記 (betw. 905-933) 9.5b-6a, D 325-26, no. 590 (on this work, see Verellen, "Evidential Miracles in Support of 
The following tale about the "The Prince of Zhongli 鐘籬大王" 60 suggests that many communities prayed to such local gods for rain:

In ancient times, ${ }^{61}$ a man dressed in a white robe with wide sleeves and wearing an archaic headdress 冠幘 is said to have appeared at Tang village 唐村 on the east shore of Suizhou 遂州 (modern Suining). ${ }^{62}$ Standing to one side of the road, he said to the villagers: "I am the prince of Zhongli. ${ }^{133}$ For a long time, I had a temple some 1000 li downriver. ${ }^{64}$ Because it was destroyed by the waters, my statue is now traveling upstream. ${ }^{65}$ It is about to arrive. You should build a temple for me here." The villagers went to the river to look for it. They found a wooden statue several feet tall and named it the God of Tang village 唐村神. To this day prayers concerning drought and inundation ${ }^{66}$ are unfailingly answered. It is said that the original apparition had the appearance of a Taoist. ${ }^{67}$

The importance of $\mathrm{Li}$ Bing as one of the region's great tutelary gods ${ }^{68}$ was meanwhile never in doubt. The Record of Marvels features a story about the miraculous removal of a dike in the river Min 岷江 by Li Bing and his spirit soldiers during a flood in $910,{ }^{69}$ an incident of some interest to the history of the irrigation system in the Chengdu plain. As it has a bearing on the legitimation of the Wang Jian 王建 regime (907-918), we will return to it under that heading below.

The Record of Marvels dwells not only on the gods of Shu and their cults; it also

Taoism," T'oung Pao 78 (1992): 217-63; the story in question is translated in "Luo Gongyuan," 303-306). On the popular aspects of the cult, see also Yusa Noboru 遊传笲, "Ra Kōen to minkan shinkō 濰公䔔と民閶倍仰,” in Dōkyō to shūkyō bunka 道教と宗教文化, edited by Akizuki Kan'ei 秋月觀暎, 245-63, Tokyo: Hirakawa, 1987.

6) LJ 4.4b-5a; ap. TG 313.2478.

61 TG var.: "Formerly."

62 The government seat of Suizhou was situated on the west bank of the river Fujiang 涪汭. Tang village was apparently on the opposite river bank. The present story is joined to the preceding, "Zheng Junxiong 郱君雄," set in the same locality (see below), without typographic break. I treat them as separate entities, as did the editors of Taiping guangji.

63 TG var.: "wang $\mp$. for “dawang 大 $\mathrm{x.."}$

64 Some $100 \mathrm{~km}(200 \mathrm{~b})$ to the south, the Fujiang joins the Jialing 点陵 at Hechuan 合川 (Tang Hezhou 合州; cf. “Magistrate Cui 崔令” above). Nearly $100 \mathrm{~km}$ further, the Jialing flows into the Yangzi (at modern Chongqing). Note, however, the TG variant "10" for "1000."

65 On the motif of this miraculous feat, see also Daojiao lingyan ji 4.5b-6a.

6 if The phrase "concerning drought and inundation" is omitted in TG.

67 Archaic, Han-style dress is frequently associated with Taoists in these pages and elsewhere in Du's writings (cf. Verellen, "Encounter as revelation").

68 See Luo Kaiyu 維開玉, Zhongguo kexue shenhua zongjiao di xiehe: yi Li Bing wei zhongxin 中國科學神話宗教的協合 — 以李冰為中心, Chengdu: Shu Ba shushe, 1990.

60 LJ 4.4a; ap. TG 313.2477. 
peoples the region with immortals, recluses, scholars, diviners, and holy men of the broadest description: In the seventh century, the Chengdu Taoist and Daode jing commentator Li Yuanxing 黎元興, ${ }^{\circ}$ obtains divine aid for the construction of a temple to Lord Huang-Lao (see also below); several stories exalt the virtues of Sichuan recluses, such as Zhu Taochui 朱桃槌 and Mao Yihuan 毛意歡. Du's account of the former ${ }^{71}$ is compiled from a number of local records, some of which are now lost:

Record of the Recluse Lord Zhu 隱士朱君記, 72 according to the Administrative Report of Lingchi County, Lingchi xian tujing 躍池縣圖經: ${ }^{73}$ Zhu Taochui ${ }^{74}$ was a recluse. In the first year of Wude (618), he made his home in the Bonü mao village 白女毛村 in Shu county 蜀縣. Wearing rustic clothes and makeshift headdress, he led an unassuming life in obscurity. For a living he wove shoes, and he never varied his price. ${ }^{75}$ Later he settled on a great rock by the Boma brook 白馬 溪 on Mt. Dongping 棟平山. The stone of this hillock was the color of ice, and it was as flat and smooth as a whetstone. Ten people could be seated on it. Beside the rock stood a tree which cast its spreading shade over it and provided shelter. There even the hottest months of summer seemed like autumn. Once Taochui had retired to this place, many were the cultivated gentlemen who came to visit there. On occasion, Master Zhu would practice his subtle art (literally, “carve wheels 斨輪 ") 76 as an offering to them. First the prefect Li Houde 李厚德" 7 and after him the prefect Gao Shilian 高士廉 ${ }^{78}$ presented [Zhu] with formal summonses and honored him with official missives. But the latter merely laughed at their presumption and declined to reply.

The junior guardian to the heir apparent 太子少保 Xue Ji 薛稷 (649-713) of

70 LJ $1.5 a-b$.

71 LJ 1.8b-10b. See also Du Guangting's Supplementary Lives of Immortals, Xianzhuan shiyi 仙俀拾造, in the partial reconstruction by Yan Yiping 㵨一萍, Daojiao yanjiu ziliao 道教 研究资料, 1.2: 41-42, Taipei: Yiwen yinshu guan, 1974.

72 For the following panegyric, with its preamble from the Lingchi xian tujing, see also the Zhu yinshi tuzan 朱隱士四賆 by Xue Ji 薛穔 (649-713), preserved in Qinding Quan Tang wen 欽 定全唐文 275.13b-14a, 1814 Palace edition.

73 This local gazetteer of Jianzhou 簡州 in Sichuan is now lost. See Zhang Guogan 張國涂, Zhongguo gu fangzhi kao 巾國古方志考, 673, Shanghai: Zhonghua, 1962.

74 Zhu Taochui, written 朱桃椎, has a notice among the biographies of recluses in Xin Tang shu 196.5596.

75 This "upright" behavior set him off from the merchant class. Compare the story of the recluse and medicine seller Han Kang 韓康 in Hou Han shu 83.2770-71.

76 An allusion to the consummate skill of the wheelwright 輪扁 in Zhuangzi, “Tiandao 天 道," the expression is here used figuratively, apparently in reference to Zhu's literary craft.

77 See Xin Tang shu 191.5504.

78 For the exchange of this statesman with Zhu, see his biography in Jiu Tang shu 65.2443. 
Hedong $^{79}$ wrote the following Panegyric for his Portrait 圖讃:

The Master knew sufficiency;

living in retirement, he was fond of drifting.

He never varied his price

and contented himself with one daily meal.

With beaten earth he made his dwelling,

and rolled up leaves for his cap. ${ }^{80}$

The subtlety of "carving wheels"

afforded him pleasure equal to that of the wheelwright. ${ }^{81}$

"Rhapsody on the Thatched Cottage of the Recluse Zhu Taochui"

Yinshi Zhu Taochui Maoci fu 隱士朱桃桘茅茨賦

by Xue Ji (sic) $)^{82}$

The man of quiet contemplation does not seek glory in worldly affairs. Those who retire into obscurity find pleasure instead in a life of idleness. Thus did the sage Confucius endure the ridicule of [the Spring and Autumn recluse] Jie $\mathrm{Ni}$ 年溺 ${ }^{83}$ and was the exalted Shuye 叔夜 [i.e. Ji Kang 嵇康 (223-262)] ${ }^{84}$ subjected to censure by Sun Deng 孫登. ${ }^{85}$ All the more reason to seek the joys of nature, discard ambition and please the soul. Lying dissimulated in his thatched cottage, his thoughts dwell on matters beyond the blue clouds [i.e., public recognition]. ${ }^{86}$ In withdrawing from the annoyances of this world, he will follow nothing if not the high ideals of enlightened times.

At this point follow “His Words 其辭日” (1.9b-10a), i.e. the text of Zhu Taochui's rhapsody, describing the untrammeled life of the recluse and his rapturous

79 Biographies in Jiu Tang shu 73.2591-2 and Xin Tang shu 98.2893-4.

80) A line in the rhapsody quoted below (1.9b) reads: "I cut some goose-foot 野策 to make a staff and roll up bamboo leaves for my turban if (i.e., to tie my hair)."

81 See note 76 above.

82 This rhapsody is in fact the work of Zhu Taochui himself. See Quan Tang wen 161.1a. Cf. the discussion of Du's error of attribution in the preface (2b) by Hu Zhenheng 胡德字 (1569-1644) to the Bice huihan edition of the Luyi ji.

83 See Shiji 必記 (ca. 91 BC), by Sima Qian 司墨遥, 47.1928-29, Peking: Zhongua shuju, 1959 edition.

84 See Donald Holzman, La vie et la pensée de Hi K'ang (223-262 ap. J.C.), Leiden: Brill, 1957, and idem, "La poésie de Ji Kang," Journal Asiatique 268 (1980): 107-77 and 323-78.

8.5 Sun ignored Ji Kang's request for instruction, criticizing his conduct. See Jin shu 94.2426 and Shenxian zhuan 神仙傅 (ca. 320) ap. Taiping guangii 9.63-64.

86 On this image, see Edward H. Schafer, "Blue green clouds," Journal of the American Oriental Society 102 (1982): 91-92. 
communion with nature. Du Guangting concludes his own narrative:

Earlier, when Master Xue was appointed magistrate of Pengshan 彭山, he heard of [Zhu Taochui's] reputation and was delighted. He composed the Maoci fu as a tribute to him. When he left this post and returned to the capital, he visited the place en route. [Zhu's] dwelling had since been abandoned, but recognizable vestiges remained. ${ }^{87}$ When [Xue] enquired among the villagers, he was told that Master Zhu was now present now absent, now concealed now visible: he had indeed attained immortality! Master Xue composed a eulogy (see above) on his wall and returned to Chang'an. Although in the course of the following several years Master Zhu was seen by the villagers from time to time, his dwelling remained unknown. The rock on which he had lived in retreat is no longer to be seen today. There remains only a stone cavern beneath a great tree. In recent years, the entrance to the cavern has also long been blocked. Subsequently, the magistrate and local devotees had the Rhapsody carved on a stone tablet which they erected at the mouth of the cavern and beside the public thoroughfare 官道. ${ }^{88}$ Whenever the locals supplicated, burned incense or prayed, supernatural responses occurred. If [Zhu Taochui] had not attained the Way and joined the ranks of the immortals 證品, then how could he have brought this about?

The tale of Mao Yihuan 毛意歡 ${ }^{89}$ is set at Mt. Douchuan shan 豆㘣山 in Changming xian 昌明縣 county, Mianzhou 綿州 (modern Mianyang), where the Perfected Dou Ziming 豆子明 is said to have practiced the Way. ${ }^{90}$ Virtually inaccessible, the “stone sprout 石简” (i.e. conical rock shaped like a bamboo sprout) is likened to the chuan 㘣-grain basket (made by rolling a mat into a cone). ${ }^{91}$ On the peak was a Tianzun

87 About a century had passed since the "lifetime" of Zhu.

88 This emplacement was no doubt a factor in the subsequent development of the local cult. Cf. the position of Julong hongdao's hut near the government road below.

${ }^{89}$ LJ 6.5b-7a; ap. Quan Tang wen $934.2 b-3 b$, as “Douchuan shan 묘 圆山記.”

() Also written Dou Ziming Douchuan shan Yunyan si Feitian zang 四川汀油翼圆山零岩寺飛天藏," Wenwu 文物 1991.4, 20-33. Huang cites the present story as the earliest written record regarding this site (p. 21).

91 "Stone sprouts" or conical pillars are a recurring theme in Sichuan mythology. Cf. the “stone cone" pillars containing cinnabar in the Shenxian ganyu zhuan 神仙感遇傳 (ca. 904) of Du Guangting, 4.4b-5b, D 328, no. 592 (on this work, see Verellen, "Encounter as revelation") and the same author's now lost Shisun ji 石简記 (Du Guangting, 211). Frequently the cones are associated with ancient tomb pillars 厥. See the "Chengdu lingmu 成都筑菜" story (LJ 8.6b-7a) discussed below. The Huayang guozhi relates that the Kaiming kings of Shu had five Strong Men 五丁力士 who could move mountains and lift weights of ten thousand jun. When a king died, they erected megaliths to mark the tomb. These were the so-called "stone sprouts." The royal burial site was called "Bamboo Sprout Village." See Huayang guo zhi jiaobu tuzhu, 122-23, and Sichuan sheng wenshi guan 四川省文边䬼 ed., Chengdu chengfang guji kao 成都城坊古路考, 326-28, Chengdu: Sichuan renmin chuban she, 1987. 
gugong 天尊古宮 temple of unknown date. In ancient times, immortals used a bridge made of bamboo rope to get there. But over the years it decayed and the route had been cut off. During the Xiantong reign era (860-874), the Taoist master Mao Yihuan 毛意 歡 lived at the foot of this mountain. A devout disciple from youth, he was forever reciting the Five Thousand Word Classic 五千言 (i.e. the Daode jing). Clad in rough garments, he daily went to market where he recited the scripture and begged for wine. When drunk, he would return to the mountain, clambering up the precipitous slope. Where the road was cut off, he had made a precarious bridge by tying ropes between the pine trees 白松. Mao Yihuan was said to have retired to a cave there, where he read the scriptures. Believed to have become an immortal, he was occasionally seen crossing his rope bridge, holding a lamp and a wooden bowl. The narrative ends on a characteristic hagiographic note: Many poisonous snakes and ferocious tigers lived on Mt. Douchuan. Locals dared not venture there alone. Yet Yihuan was fearless, even at night. At the approach of visitors, two crows 鴉 would take to the air and cry an advance warning to Yihuan.

Jing Zhiguo 景知果 ${ }^{\$ 2}$ was also, by virtue of his spiritual power, a tamer of wild animals. He lived with tigers and leopards on Doutu shan 䔈圆山 in Jiangyou county 江油縣, ${ }^{33}$ and tamed them like domestic dogs. Wild birds and great snakes were at his beck and call. Tigers came on moonlit nights and pranced about his courtyard until he chased them away. Zhiguo was cutting grass beside the temple when a rabbit lay there in his way. He moved it aside with his hand as if it had been a cat or a dog. He was on such familiar terms with the different species 異類. One morning he vanished.

The power to transcend the natural boundaries between species was also given to paragons of filiality: Yin Xuanzhi 陰玄之, ${ }^{94}$ a native of Zizhou 資州 (modern Zizhong) and student of the Five Classics and Zuozhuan, lived in a mourning hut by the tomb of his father, while tigers, ghosts, and spirits joined him in his lament. At night lights appeared to shine in front of the tomb. ${ }^{95}$ After the death of his mother, Xuanzhi again mourned for six years in a hut. When his grass shed became dilapidated, he went to live in a cave, wailing and reciting. His motto was: "To seek fame and advancement is not for me. Since both my parents have passed away, a salary could not nourish them. And what's the use of fame?" Yin never sat an examination and spent his entire life in poverty and hardship. He died aged over eighty.

Yang Taibo 楊太博 ${ }^{(\boldsymbol{S}}$ was also a native of Zizhou 資州 who mourned his father and mother in a hut. His devotion was rewarded by the apparition of a supernatural

92 LJ 2.4b-5a.

93 In the same area as the Douchuan shan, also written graphic similarity of the second characters suggest that they are variants of the same name. See also Huang Shilin, "Sichuan Jiangyou Douchuan shan."

94 LJ 3.5a.

95 Cf. “Duan Wenchang 段文昌” (LJ 4.3a-4a) and “Yang Zhiyu 劭知遇” (LJ 4.5a-b), discussed below.

${ }^{\Re}$ LJ 3.5b; ap. Shuofu 118.4a-b. 
light, a tame tiger and auspicious white rabbit. When the ministers, princes, dukes, and finally the emperor of Shu (Wang Jian) heard about it, they sent down an official commendation and had a notice erected at his dwelling.

Julong hongdao 句龍弘道, ${ }^{\prime 7}$ another local saint and paragon of filial piety, lived in the same area, beneath Mount Zitong 梓潼山. Having left the military, he lived in a mourning hut by his parents' tombs, near the government road 官路 that passed $\mathrm{Zi}$ tong. ${ }^{98}$ Julong hongdao reached over eighty years, wore long hair, and on each tomb [auspicious] purple fungi 紫芝 grew. Fierce and wild animals became tame and docile. In 881-882, when Xizong inspected Shu (on exile from the capital during the Huang Chao rebellion), he personally visited the hut and sat in its front yard. When the imperial retinue returned [to Chang'an] in 885 , they again journeyed close by, and the emperor bestowed gifts on the eccentric paragon. Finally, when they stopped at Jianzhou 劍州, on the point of leaving the region, an order was issued to return his land tax. Three years later he was awarded a testimonial of merit.

The religious landscape of Shu as it emerges from the pages of the Record of Marvels is, despite its Taoist penchant, eclectic. Presumably, an ecumenical outlook was appropriate to the functions of a court Taoist, and Du Guangting's writings by and large reveal a keen and broad-minded observer. ${ }^{99}$ Beside distinctly heterodox cults, Taoist immortals, and saintly figures of a Confucian persuasion, Buddhism also made its mark here, for example, in the tale of the monk Wang Huijin's 王惠進 brush with the Grim Reaper in Chengdu in the year $911:^{100}$

At the beginning of the Yongping reign (of Wang Jian, 911-915), there was a monk Huijin, surnamed Wang, who lived at the Fugan si 福感寺 monastery. ${ }^{101}$ Having gone out early [one morning] and arriving at the gate of the Zifu yuan 資福 院 oratory, he saw a tall man there, his body indigo blue. Startled, Huijin fled to avoid him. Arriving at the Bamboo Mat Bridge (Zhuqing qiao 竹等橋), he hurriedly entered the home of a family of the people 民家. The other also arrived on his heels. They struggled for a while, and when the monk was unable to extricate himself, he begged for mercy. The other asked: "What's your name?" He answered that he was surnamed Wang. The man said: "You have the same given name but a different surname." He then took his leave and departed. Shaken by the struggle, the monk put up with the local family. Only after a while, when he was feeling somewhat calmer, did he return to the monastery. That very night someone with the

97 LJ $3.5 b$.

98 The main road between Chang'an and Chengdu: clearly a factor in the official attentions this recluse enjoyed.

99 Cf. the remarks concerning the tension between Du's occasional polemical writings and his "official" ecumenical outlook in the conclusion to Verellen, "Evidential miracles."

100 LJ 4.9a-b; ap. TG 354.2805.

101 Situated north of Little West Gate, Xiao Ximen 小西門, in Chengdu; see Daojiao lingyan ji ap. Yunji qiqian 雲笼七筑 (ca. 1028), 122.8a, D 677-702, no. 1032. 
same given name but a different surname had died there.

The following story adapts a Buddhist devotional theme: ${ }^{102}$ The Taoist master Wang Faxuan 王法玄 ${ }^{103}$ of Kuizhou 䇋州 (modern Fengjie) had a long tongue that caused him to pronounce his words indistinctly. Because this vexed him constantly, he vowed to recite the Daode jing. He dreamt that Lord Lao appeared and clipped his tongue. When he awoke, the words and phrases came lightly and he was able to recite the Five Thousand Words (of the Daode jing).

The reworking of hagiographic traditions and their transmission in the context of the religious culture of tenth-century Shu can also be seen in narratives concerning such well-known figures as Lord Xu 許君 ${ }^{104}$ and Li Deyu 李德裕. ${ }^{105}$ The first, recounting a spiritualist incident in the life of the immortal $\mathrm{Xu},{ }^{106}$ demonstrates the importance of preserving tomb stone inscriptions and traces the origins of the Great Water and Land Offering 水陸大醮. The author identifies the story as a "tradition reported by a Chengdu Taoist." The second concerns the statesman and army chief 太尉 Li Deyu's (787-850) penchant for curios. ${ }^{107}$ A mysterious old man presents Li with a treasure object hidden in a cavity inside a mulberry tree: A specially skilled craftsman "then opened it out into two hollow pieces shaped like a pipa 琵琶 lute. This spontaneously produced [two] white doves, complete with feathers, wings [TG: beaks], and feet. Because of a small fault in the craftsmanship, he had missed the correct thickness, and one dove was lacking its wings. The duke submitted the complete one, keeping the other. It exists to this day among the people. The deputy secretary of the Water Board 水 部員外 Lu Yanrang 盧延譲 was told these matters by the army chief s grandson.” Lu Yanrang (jinshi 900), a colleague of Du Guangting's, was an author, poet, and high official at the court of the Former Shu who reached the rank of vice-president of the Board of Justice under Wang Jian. ${ }^{108}$

Another court figure of the Former Shu, the diviner Ma Chuqian 馬處謙, features

102 LJ 2.6b-7a; ap. TG 162.1172; Shuofu 118.3a; Leishuo 8.18a attributes this story, wrongly it seems, to the eighth-century Guangyi ji 廣異記 (cf. Dudbridge, Religious experience, 236).

103 TG, Leishuo var.: “Wang Falang 干.法朗."

104 LJ 1.7a-b; ap. TG 72.452-53.

105 LJ 2.7b-8a; ap. TG 232.1778; Shuofu 118.3a-b.

106i See Kristofer M. Schipper, "Taoist ritual and local cults of the T'ang dynasty," in Tantric and Taoist studies in honour of R.A. Stein, edited by Michel Strickmann, 3: 812-34, Brussels: Institut Belge des Hautes Etudes Chinoises, 1985.

107 See his biographies, with those of his sons, in Xin Tang shu 180.5327 and Jiu Tang shu 174.4509-31; on Li's taste for curios and reputation as a collector, see R. H. van Gulik, "The 'Mango Trick' in China: An essay on Taoist magic," Transactions of the Asiatic Society of Japan 3rd ser. 3 (1954): 117-75, and Edward H. Schafer, "Li Te-yü and the azalea," Etudes Asiatiques 18/19 (1965): 105-14.

108 See his biography in Shiguo chunqiu 十团谷秋 (1678), by Wu Renchen 坚任臣, 44.2a-b, Peking: Zhonghua shuju, 1983 edition. 
in the story "Hu Tian 胡恬," ${ }^{(\infty)}$ an expert, among other things, in casting horoscopes by means of the sidereal calendar 星曆推步, alchemy, longevity, Yijing divination 易占術, calligraphy, poetry, song, and breathing techniques 鍊氣, active at Mt. Bohe 白鶴山 in Xiangyin county 湘陰縣, Yuezhou 岳州 (near Changsha, Hunan). Ma Chuqian, we are told, probably via his own testimony, was Hu Tian's disciple. "As a result, though Chuqian told fortunes, he never performed sacrifices and prayers (following Hu's injunctions). Later he served the Shu kingdom as shaojiang 少將 officer and as honorary executive 撿校僕射."

The last story in this section, "Zhao Yannu 趙瑟奴," 110 despite the subject's supernatural birth and classification as an “extraordinary being 異人” along with the various saints discussed above, exemplifies the zhiguai writer's primordial interest in anomalies, including freaks of nature. As often in Du Guangting's writings, the more fantastic the ostensible subject matter, the more realistic his sociological and ethnographic observation, in this instance offering vivid glimpses of local economic life and popular festivals:

Zhao Yannu was a native of Shijing 石鏡 in Hezhou 合州 (modern Hechuan; cf. note 64 above). He lived on the grounds of Dayun monastery 大雲寺. Earlier, his mother had become pregnant and after a few months given birth to a tiger that she abandoned in the river. Then she became pregnant again, and a few months later gave birth to a large turtle. She abandoned it also and became pregnant again. After few months she gave birth to a Yaksha 夜叉 of more than a foot in length. She abandoned it. She became pregnant again and after a number of months gave birth to Yannu.

His eyebrows, eyes, ears, nose, and mouth were all complete. From his neck downward his body was like a cut-off gourd. He also had shoulders and a torso a well as two hands, each several inches long. Though he had no elbows, forearms, wrists, and palms, six fingers grew on each of his [two] round [stumps of] flesh, over an inch in length. They had claw-like nails. Below, his two feet were also one or two inches each, again with six toes. When his mother had given birth to him, she could not bear to abandon him. When he grew older, he only grew to something over two feet.

[Yannu] was skillful in the water and could ride a boat. By character he was crafty, quick-witted, and eloquent. He was fond of killing and made his living from fishing and slaughtering pigs. At every boat race and [exorcistic] expulsion ceremony 驅儺 and whenever there was a competition in performing the "Song of the Bamboo Branches 竹枝詞" [Yannu] was always the champion. For all transac-

109 LJ 2.11a-12a. Cf. the biography of Hu Tianru 胡恬如 (sic) in Tushu jicheng 圖書集成 284.13b, quoting Fangwai zhi 方多志, which is close to this text. See also Beimeng suoyan 北萝 瑣言, by Sun Guangxian 孫光惠 (d. 968), 169, Shanghai: Guji chuban she, 1981 edition, quoted in TG 215.1650.

110 LJ 2.9b-10a; ap. TG 86.565. 
tions in the marketplace he acted as broker. His head was usually shaven and he wore a black garment. He was popularly known as Master Zhao 趙師. In his later years he was content to be bald and wore only a white tunic. Sometimes when he knelt in obeisance, danced or leaped, or fell to the ground, he would expose his body, to the great merriment of bystanders. When he rode on a mule to distant places he got someone to lift him up and lay across the saddle like a sack.

[Yannu] had two wives and one daughter. [In his household] clothing and food were plentifully provided. If his family were attacked, nothing could hold his strength in check. In the year 919 he was just sixty years of age. His girth measured several spans. His face and eyes were no different from those of ordinary people. The middle finger on his daughter's right hand was seven or eight inches long: She too was no ordinary being!

\section{SACRED SITES AND NATURAL HISTORY}

The territory of Shu was a network of cult sites and places associated with the activities of holy and extraordinary beings; grottoes, waters, stone formations, tombs, and temples were also endowed with numinous power. The following examples from the Record of Marvels are discussed in that order.

Magu grotto 麻姑洞, ${ }^{11}$ at Mt. Fanyang 繁陽山, the first of the Twenty-four Dioceses 二十四治 [of Heavenly Master Taoism], is another name for Yangping 陽平 [diocese]. ${ }^{112}$ It is situated on the yang (i.e. northern) shore of the river Fanshui 繁水, hence the name. The Benji jing 本際經 scripture ${ }^{113}$ says: “The place where the Heavenly Master Zhang Daoling 張道陵 went and the Most High 太上 expounded the scriptures." [The diocese] is situated south of Xindu county 新都縣 in the superior prefecture of Chengdu 成都府. Fifteen $l i$ across the river, an isolated peak rises from the mountain chain: That is it.

Magu grotto and Yanyang grotto 焰陽洞, another holy place of the ancient Heavenly Master community, were both sites of miracles confirming the legitimacy of Wang Jian. ${ }^{114}$ We will return to them later in that context. The Warm Water Grotto (Wentang dong 溫湯洞), ${ }^{11.5}$ meanwhile, was situated beyond Kaizhou 開州 prefecture (modern Kaixian, in Eastern Sichuan) and east of Mt. Yisheng 倚盛山. There was also a Wentang

${ }^{11}$ LJ 6.2b-4a; ap. Quan Tang wen 934.1a-2b.

112 Cf. Wang Chunwu 王純五, Tianshi dao ershisi zhi kao 天師道一十四治考, 96-97, Chengdu: Sichuan daxue chuban she, 1996.

113 See Wu Chi-yu, Pen-tsi king (Livre du terme originel): ouvrage taoiste inédit du VIIe siècle, Paris: Centre National de la Recherche Scientifique, 1960.

114 LJ 6.7b-9a; ap. Shiguo chunqiu 37.536-7; Tangwen shiyi 50.24a. See Verellen, "Zhang Ling and the Lingjing salt well."

115 LJ 6.4a-5b; ap. Tangwen shiyi 50.23b. 
well 溫湯井 with a hot spring. In Linde (664-665), the entrance to the cave opened spontaneously because of a landslide after a thunderstorm and heavy rainfall. The Record of Marvel's account of the interior is of the tourist guide genre, pointing out every holy site and point of interest in turn: Naturally formed stone bells 石鐘, stone figures like vajra warriors 金剛力士, a stone stele 石碑 supported by a large tortoise, both naturally formed, without an inscription. Next to it stood a large screen, with ding 鼎-tripods. The visitor next enters a narrow cave by an ordinary-looking path, passing stalactites 石滴乳 ranged in order, stone formations in the shapes of dragons, unicorns, luan ually capitulates with the exclamation “Impossible to record it all 不可殑紀!” One $l i$ further, he resumes, is the multi-storied Lotus Terrace 蓮臺. Outside the grotto, lotus flowers of stone spread over the ground, and next to them, a sweet spring 甘泉 provided clear, warm water for brewing tea. In front of it flowed a brook. Crossing it, one reached a high embankment where the path became precipitous and slippery. On top of it, there was a large hall on the walls of which travelers had recorded the years, months, and days of their visits. ${ }^{116}$

Grottoes are Taoist holy places par excellence. They are characterized by "spontaneous," grotesque stone formations. Many of them produce life-giving water. And such are the hallmarks of other natural sites with numinous or marvelous properties in the Luyi ji, as well: Red Water (Chishui 赤水) ${ }^{117}$ in Hanzhou 漢州 produced a bubbling spring as underwater channels emerged from beneath the mountain to form a large pool. Its overflow was strong enough to drive a water mill. Galloping Horse Spring (Ma pao quan 馬跑泉), ${ }^{118}$ northwest of Qingcheng xian 青城縣 (modern Guanxian), was one of the holy sites surrounding the Laojun temple 老君觀. Its water was fragrant and sweet, and never ceased flowing through the four seasons. In spring and summer it was as cold as ice, but warm in autumn and winter. Also known as the Rendezvous of the Perfected 會真, this is where the Most High Lord Lao 太上老君 met with Tianzhen huangren 天真皇人. The spring had been stamped out 跑成 by the horse that Laojun rode.

The Six Hours Spring (Liushi shui 六時水) ${ }^{119}$ on Qingcheng shan 青城山 is situated above the Zongxuan guan 宗玄觀 temple (today's Changdao guan 常道觀). Facing the temple, a precipitous cliff rises to a height of more than five hundred feet. On top of the cliff is the Transmission of the Tao Altar 授道壇, the place where the Perfected Lord Ning 甯真人 (the Elder of Qingcheng, see above) and the Yellow Emperor Xuanyuan huangdi 軒轅黃帝 had received the Way. Below, a stone niche 石躘 con-

116 See also F. Verellen, "The Beyond within: Grotto-heavens (dongtian 洞不) in Taoist ritual and cosmology," Cahiers d'Extrême-Asie 8 (1995): 267-68.

117 LJ 7.3a-b.

118 LJ 7.4 .

119 LJ 7.4a-b; ap. Shuofu 118.5a. 
tained an image of emperor Xuanzong. ${ }^{120}$ According to the sixfold division of the day (liushi 六時), the water spontaneously flowed out from the top of the cliff, never failing up until the author's own time. People made pilgrimages 遊裋 to the spring to worship and view it.

Holy or magical stones form a separate category of Marvels: “The Immortal Pu 浦 仙" ${ }^{121}$ is a story about a pair of rocks, the Eastern and Western Pillars 東柱西柱 north of Jinzhou 金州 (modern Ankang). The range of strange and graceful peaks there, the Record tells us, contained great natural pillars, hence the name. The highest peak was the place where immortal Pu had ascended into heaven.

“The shooting stars of Jiangzhou 江州流星:"122 Fifty li south of Jiangzhou 江 州 (near modern Chongqing), at the Seven-li Inn 七里店 south of the river Tuojiang 沱江, ${ }^{123}$ there are stones on top of a small hill. Greenish, hard, and smooth, they are popularly believed to contain pearls. Each year at the time of the mid-autumn festival, the fifteenth day of the eighth month, some ten of them fly about together like shooting stars, now gathering, now dispersing. The pearls hidden within the gleaming stones are said to be priceless treasures. Witnesses who surreptitiously look for them, however, find nothing.

“The porcelain incense burners 瓷香爐:" ${ }^{24}$ In the mountains of Changming xian 昌明縣 county, Mianzhou 綿州 (Mianyang), in an area of some twenty li in circumference, innumerable porcelain incense burners, upwards of two inches wide, whole or broken, are strewn about or piled up in the forest [vestiges of the ritual activities of immortals?].

“The foundation stone of the Jingyun guan temple 景雲觀基石:"125 New North Market 新北市 [in Chengdu] ${ }^{126}$ is the old foundation of the Auspicious Clouds Temple, Jingyun guan 景雲觀. There is a great stone, larger than a pillar base 柱礎. When people sit or stand on it, they are driven back by a fiery heat that affects the heart like a fever. As a result, they fall ill and frequently die. An ancient tradition says that when fire is applied to this stone, then at Qutang 翟塘 (the Yangzi gorge between Fengjie and Wushan) the mountain roars and the water boils.

120 See Verellen, Du Guangting, 129-31.

121 LJ 6.7a-b.

122 LJ 7.6b; ap. TG 398.3193.

123 A tributary to the Yangzi west of Jiangzhou, adopting here the variant reading in TG.

LJ has "Shejiang 蛇汭." The location of this is uncertain.

124 LJ $7.7 \mathrm{a}$.

125 LJ 7.7b-8a; ap. TG 398.3194.

126 Constructed by Cui Anqian 崔安潛, military governor from 878 to 880 . See Zizhi tongjian 资治通鑑 (1085), by Sima Guang 可㫮光, 253.8212-13, Peking: Zhonghua shuju, 1976 edition, and another version of the present story in Daojiao lingyan ji ap. Yunji qiqian 122.7b. The New South Market 新南市 had been due to Wei Gao 毒皇, military governor in 785-805; see Daojiao lingyan ji 15.8a. 
“Fallen Star stones 落星石:"127 In a mountain pavilion 山亭 in Jinyuan county 晉源縣, Shuzhou 蜀州, there are two large stones. More than two feet in diameter, they emerge seven or eight inches from the ground. If people sit on them, they feel a pain in the heart and are often doomed. In fact, these are fallen stars. The one to the east is alive to supernatural manifestations 霝驗, the one to the west as dead as any stone. Both are greenish-white in color.

“Stone bells 石鐘:" ${ }^{28}$ Near the Pacification Army Garrison 鎮靜軍, there are stones in the river bank, five or six feet long and three or more feet high. When struck, they sound like bells. Commander Liu Shijian 劉師冷 presented one stone that was more than four feet long, round in shape, and of a green color. When struck, it sounded like a chime. ${ }^{129}$

Tombs and temples were numinous sites by definition. Following are two examples of tombs from the Chengdu area: The great tomb of Xu Jing 許静墓 ${ }^{130}$ was situated in the fields seven or eight $l i$ directly west of the Yanqiu men 延秋門 gate of Chengdu. ${ }^{131}$ It was said that this was the tomb of general Xu. When ploughmen, shepherds or domestic animals desecrated it, disaster inevitably ensued. In the fields outside, many tombs had disappeared. Only this one survived. People dared not trespass against it. Jing was an official under the Former Shu 前蜀 (referring here to the Sanguo kingdom). He reached the prestigious honorary rank of dasi tu 大司徒.

"A numinous tomb in Chengdu 成都靈墓:" 132 In Qiande 3 (896), the director of instruction Li Shitai 李師泰 (d. before 908) discovered near the Li Bing temple in Chengdu a quantity of "barbarian" coins. The site was the ancient tomb of an unknown occupant, situated near a cone-shaped stone 石简, which was thought to be ancient tomb pillar 關 (cf. n. 91 above). Li ordered the coins to be reburied and the tomb left undisturbed, winning the author's approbation.

Unlike tombs, extraordinary temples do not form a separate category of records in the Luyi ji; the following examples have been regrouped from various chapters:

127 LJ 7.8a; ap. Shuofu 118.5b.

128 LJ 7.8a.

129 Cf. the "naturally formed" stone bells of the Wentang grotto 溫湯洞 above. These were as large as "several-thousand-pound bells;" they hung suspended two feet above the ground, were solid inside, and gave no sound when struck (LJ 6.4a-5b). In the organic universe of the Record, these spontaneous formations echo the great feat of ancient bronze-casting, the ritual bells described in Lothar von Falkenhausen, Suspended music: Chime-bells in the culture of Bronze Age China, Berkeley and Los Angeles: University of California Press, 1993.

130 L) 8.3b-4a. The graph for his given name appears to be an error for 靖; see his biography in Sanguo zhi 三國志 38.963.

131 The main western gate of Chengdu at the time; see Chengdu chengfang guji kao, map after p. 64 .

132 LJ 8.6b-7a; ap. TG 390.3118-19 (TG erroneously attributes this narrative to the late eighth-century Guangyi ji 廣異記 and gives the name as Li Sigong 李思恭). See the translation and historical background in Verellen, Du Guangting, 135-36. 
“Li Yuanxing 黎元興:"133 In the Longshuo reign period (661-663), the Taoist master Li Yuanxing ${ }^{134}$ of the Realized Perfection Temple (Zhizhen guan 至真 觀 $)^{1: 35}$ in Chengdu wanted to construct a temple at Xueshe shan 學射山.1:3i One night he dreamt that a divine being 神人 led him onto a high mountain and into a great hall where he paid homage to Lord Huang-Lao of the Center 中央黄老君. ${ }^{137}$ His body was several tens of feet 丈 tall, his moustaches and beard brilliantly white. He wore a golden phoenix cap and was clad in a cloud-patterned robe. ${ }^{138}$ More than ten guards were in attendance. Turning to Yuanxing, he said: "I have timber nearby that will be suitable for the construction of this temple. There is no cause for anxiety." This dream recurred.

A few days later, while fishing from a boat on Wansui lake 萬藏池, someone saw through the limpid water a large number of logs on the bottom of the lake. This was reported to Yuanxing who sent men to retrieve them. They obtained more than a thousand logs of Black Willow 烏楊 wood, some of them up to a hundred feet $尺$ in length. With this [Li Yuanxing] erected the temple. He built a Lord Huang-Lao Hall and had a statue sculpted in the likeness of the dream appearances. He also constructed a Three Worthies Hall (Sanzun dian 三尊殿). With a predication room and altar area for the Retreat 齋, rooms and galleries, gates and roofs, there was sufficient wood for everything. ${ }^{139}$

“Yang Zhiyu 楊知遇:" ${ }^{140}$ In Guangdu county 廣都縣, there is a temple dedicated to Third Master Pangu 盤古三.郎 where many supernatural responses have occurred. When people pass the gate even slightly lacking in respect, [the god] unfailingly manifests his supernatural power: They are either struck down or toppled in their path. As a result, the place is feared and revered far and near. ${ }^{141}$

1333 LJ $1.5 a-b$.

134 Cf. above. On his Daode jing commentary, see Isabelle Robinet, Les commentaires $d u$ Tao tö king jusqu'au VIIe siècle, 107, Paris: Collège de France, 1977.

135 Also known as Longxing guan 能與觀. Cf. Daojiao lingyan ji 2.6b; $11.11 \mathrm{a}$. On Li Yuanxing's activities there, see Lu Zhaolin's 塔照鄰 (ca. 635-ca. 689) inscription Yizhou Zhizhen

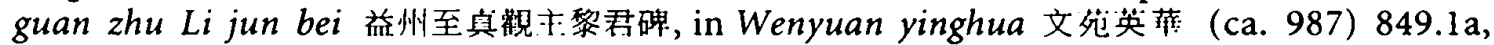
Peking: Zhonghua shuju, 1966 edition.

136 Situated 18 li north of Chengdu county; see Chongxiu Chengdu xian zhi 重修成都縣志 (1873) 1: 150.

137 The title refers to the central position among the Nine Palaces 九富 that was occupied by Huang-Lao jun.

138 On these iconographical elements, cf. F. Verellen, "A forgotten T'ang restoration: The Taoist dispensation after Huang Ch'ao," Asia Major 3rd ser. 7.1 (1994): 115-17.

139 Cf. the theme "wunderbarer Tempelbau" in Wolfram Eberhard, Typen chinesischer Volksmärchen, 239-40, Helsinki: Academia Scientiarum Fennica, 1937.

140 LJ 4.5a-b; ap. TG 313.2478.

141 The last three phrases are omitted in the TG version. 
Yang Zhiyu, a native of this county, had in the past received the Register of the Orthodox One Alliance 正一盟威籙. ${ }^{142}$ One night, he found himself heavily drunk and wanting to return home. The way was long and there was no moon. Thus, passing the temple gate, he gave a great shout: "I am a disciple of the Orthodox One. I am drunk with wine and there is no moon. ${ }^{143} \mathrm{I}$ am returning home unescorted and wish for divine assistance to show me the way back." Presently, a burning torch appeared out of the temple gate. It guided him all the way to the vicinity of his home, a distance of more than twenty li. Even crossing narrow bridges and traveling along small paths he never lost his footing. The torch then disappeared. The local villagers marveled at this with even greater apprehension. ${ }^{144}$

“Lin Tingyong 鹳庭䔨:"145 The [Heavenly Master] diocese of Jiyang 吉陽治 is in the southern part of Fuzhou 涪州 (modern Fuling). ${ }^{146}$ Thirty li upstream along the river Qianjiang 黔江, there is a temple with a [TG: supernatural] statue. An old stele still remains there as well as various objects that people dare not desecrate. The younger sister of Lin Tingyong, a vice-general 裨將 in Fuzhou, went into this temple and stole some objects there. Thereupon she lost her way; within a few days, her body transformed into a tiger... (see also above).

"Mt. Demon City (Guicheng shan 鬼城山):" 47 On the thirteenth day of the seventh month of the year renzi 壬子 (9 August 892), torrential rains caused a landslide on Guicheng shan at [Mt.] Qingcheng 青城, just behind the Zhangren temple of the Elder 丈人觀, i.e. Feng Ningzi (cf. above). This accident re-channeled a local stream past the kitchens at the temple, providing the community with a convenient supply of fragrant water. $^{148}$

A final set of entries that can be said to contribute to a distinctive sense of place in

142 See Kristofer Schipper, "Taoist ordination ranks in the Tunhuang manuscripts," in Gert Naundorf et al. eds., Religion und Philosophie in Ostasien: Festschrift für Hans Steininger, 127-48, Würzburg: Königshausen, 1985.

143 The last three sentences, corresponding to one complete column in the Daozang edition, are missing from the TG version.

144 On the theme of the supernatural torch lighting the way for the holy caught in a state of inebriation in a dark night, see also "Yin Xuanzhi 隍玄之" (LJ 3.5a) and “Duan Wenchang 段文昌” (LJ 4.3a-4a; ap. TG 138.991, Leishuo 8.25a-b). On this topos, see also Kenneth DeWoskin, Doctors, diviners, and magicians of ancient China: Biographies of fang-shih, 51, New York: Columbia University Press, 1983.

145 LJ 5.3b; ap. TG 431.3498-99.

146 Number eight of the supplementary set of "movable dioceses 遊治;" see Tianshi zhi yi 天師治儀 (ca. 552), compiled by Zhang Bian 張辯, ap. Shoulu cidi faxin yi 受籍次第法信倿 (Tang), 25a, D 991, no. 1244. This text localizes the diocese in Ye county 鄴縣, Wei commandery 魏郡 (modern Linzhang, Henan).

147 LJ 6.7a.

148 See also Daojiao lingyan ji $9.9 \mathrm{~b}$ and Verellen, Du Guangting, 133. 
the Record of Marvels describes the unusual characteristics of the local fauna or, more exceptionally, flora. For example: In the third century a stone drum 石鼓 was discovered in distant Jiangsu, ${ }^{149}$ after an embankment had collapsed in a landslide. The stone drum gave no sound when it was struck. Emperor Wudi (r. 265-290) asked the famous collector of mirabilia Zhang Hua 張華 (232-300) to explain this phenomenon. Zhang said: "Get the wood of the tong 桐 tree (paulownia tomentosa) in Shu and carve it into the shape of a fish. Struck with that, it will sound." His instructions were followed and indeed the sound could be heard several $l i$ around.

“The rabbit head snake 兔頭蛇:"1.50 In the area between Jianzhou 劍州 (modern Jian'ge) and Lizhou 利州 (modern Guangyuan, both in northern Sichuan), there are snakes about three feet long. The rabbit head snake has a white body from the neck down. It is given to attacking people; it goes for their vital arteries to drink their blood. This snake is also called Slope Nose 阪鼻. It thrusts its nose out of its burrow and lows like cattle. This can be heard several $l i$ around and causes the earth to shake. When locals burn the fields in the winter, these snakes are sometimes burnt to death. They consist mainly of fatty tissue 脂.

“The little snake of Pixian 郜縣小蛇:"151 In Pixian county (fifteen km northwest of Chengdu), town people found a small snake by the side of a drain ditch in the southern suburb. It was more than a foot in length. They cut out its five viscera, coiled and bound it and placed it on a smoky fire. It was left there to dry for several days. Meanwhile, a young child in the family suddenly suffered red swellings on its entire body. Its skin was covered with severe burns. The child groaned strangely and said in its own words: "Your family has killed me without provocation, cut out my innards and placed me on the fire. Now I order the child to suffer the same pain and hardship." The alarmed family retrieved the snake, removed the pared bamboo spit, and sprinkled the animal with water. Then they burnt incense, prayed for forgiveness, and returned the snake to its old place. After a while it wriggled and disappeared. ${ }^{152}$ Subsequently, the child also recovered and was healed.

149 LJ 7.8a-b; ap. TG 398.3185. For another version of this episode, see Verellen, "A forgotten restoration," $120-21$.

150 LJ 5.7a.

151 LJ 5.8a-b; ap. TG 459.3755.

152 On the theme of supernatural creatures impervious to boiling and burning, see also “Shujiang bie 䖝汭憋” (LJ 5.6b-7a; ap. TG 467.3849): While the turtle was being boiled in a cauldron, it moved and played about the whole night unperturbed. More fire was added during the day. The water boiled but the turtle wouldn't die. Thereupon the local people became alarmed, fearing it might be a dragon. They threw it back into the water where it swam off and was never seen again. Similarly, "The turtle of Bianhe 泣河鹅" (LJ 5.5a-b; ap. TG 472.3890): A merchant moored his boat on the river Bianhe (Henan/Anhui). He caught a great turtle and roasted it in the ashes of his stove. The merchant forgot to take it out that night. Next morning the shell was already charred. After a while, the turtle thrust out its head, moved its feet, and began to slowly walk around. The merchant threw it into the water and it swam away. 
“Shanyu 鱔魚 eels:" ${ }^{153}$ Scholar Hou 侯生, also of Pixian 隗縣, caught eels by the side of Hemp Pond, Ouma chi 漚麻池. The larger ones were up to a foot in circumference. When cooked and eaten, they had the power to restore white hair to black and cause loose teeth to grow firm again. As a result, Hou enjoyed vigorous health.

“The fish of Bo Jun 柏君魚:"154 At the beginning of Tianfu (901), Feng Xingxi 馮 行裝 ${ }^{1.55}$ took control of Jinzhou 金州 (modern Ankang). In Shuinan district 水南鄉 of Xunyang county 洵陽縣, at the Lemo rapids 勒漠潭 of the river Hanjiang 漢江 (i.e., Hanshui 漢水), the commoner Bo Jun 柏君 ${ }^{156}$ caught a fish several feet long. On its body were characters that read: "Traverse the sea three times and twice journey up the Han. Go as far as Lemo. You are destined to belong to Bo Jun."157

“The hoopoe 戴勝:" 158 The later vice-president of the Board of Justice 刑部侍郎 under the Wang-Shu 王蜀, Li Renbiao 李仁表, sojourning in Xuzhou 許州 prefecture (modern Xuchang, Henan), prepared to offer a tribute to the Spring Office 春官 (i.e. the Board of Rites). At the time, the head of the Department of State Affairs 尚書, Xue Neng 薛能 (d. 881 ) ${ }^{159}$ was governor 鎮 there. Renbiao had made a clean copy of a collection of his poems in order to offer them as a gift and was leaning on a low table in a pavilion perusing them, when suddenly a hoopoe 戴勝 flew in from under the eaves and trustingly alighted on the table. After a while, it stretched its neck, dropped its wings, and began to dance, facing the man as if it were about to speak. This went on for some time, as it revolved and danced repeatedly. Then it took to the air and flew away. Li inwardly thought this strange, but did not mention it to anyone. The next day he presented his poems. Xue ${ }^{160}$ received him courteously. After Li had stayed a few days, Xue gave him his daughter in marriage. ${ }^{161}$

15.3 LJ 5.8b; ap. TG 465.3829.

154 LJ 5.8b-9a; ap. TG 467.3849; Leishuo 8.27a-b.

1.55 See his biographies in Xin Tang shu 186.5425, Jiu Wudai shi 俩五代史 15.209-211, and Xin Wudai shi 新五代史 42.464-65. On Feng's invasion of this area and his subsequent appointments by emperor Zhaozong, see Jiu Wudai shi 15.210 and Xin Wudai shi 42.465.

1.56 Leishuo var.: "Huan Jun 桓君."

157 In a similar vein, see also "Yishu 義鼠” (LJ ap. TG 440.3586). The main entries for this small, mouse-like creature and other rodents in the Record of Marvels are borrowed from the Yiyuan 異宛 of Liu Jingshu 劉敬叔 (d. ca. 470) - here followed by the remark: “According to the popular saying, seeing an yishu presages good fortune. They can be found in Chengdu." Among insects, under the heading "Shedu 舍毒" (LJ ap. TG 479.3946), a mosquito 蚊蛃 is mentioned that lived in mountainous areas near rivers, especially in the environs of Chen 椰 prefecture (Hunan), whence it traveled up the Yangzi to Shu.

158 LJ ap. TG 463.3814-15. Li's biography in Shiguo chunqiu 42.623 seems to be derived from this story.

159 See his biography in Tangshi jishi 唐詩紀事 (1224), by Ji Yougong 計有功, 60.916-18, Shanghai: Shanghai guji chuban she, 1987 ed.

160) For Dajia 大加, read Dazhuo 大拙, Xue Neng's zi.

161 See, in a similar vein, the story "Strange crows at Mount Xianju 仙居山異鳥” (LJ ap. 


\section{THE MANDATE OF SHU}

The object of certain tales involving strange animals in the Record of Marvels, such as “The golden snail 金蝸牛” mentioned above (note 18), was to confirm the legitimacy of the Shu regime or of their Tang "predecessors." Most of these involve supernatural tortoises, as in the following example:

“The Brilliant Emperor 明黃帝," 162 Tang Xuanzong (r. 712-756) was presented a small tortoise by a master of arcana 方士. One inch in diameter and of a golden color, the delightful 可愛 small creature was kept in a pillow box. It was said to be divine and did not eat. It also had a reputation for warding off great poisonous snakes. Once the emperor was obliged to banish to the deep south a favored eunuch attendant 小黃門 who had became implicated in a kinsman's crime. Xuanzong bestowed this tortoise on him to protect him against pythons. In Xiangjun 象郡 (Guangxi), the palace attendant stopped at a lonely inn to pass the moonlit night there. Gradually the sound of wind and rain drew near. The attendant set out his tortoise at the top of the steps. After a while the spirit tortoise stretched out its neck and exhaled its $q i$ 氣. [A screen of] fire rose around it, like a yan 綖-crown ornament, to a height of three or four feet. After it had gradually dispersed, the tortoise returned to normal. The sound of wind and rain had stopped abruptly. The next day it transpired that dangerous snakes had released their poisonous $q i$ to avenge one of their kin accidentally killed by the roadside. ${ }^{163}$ Thanks to the protection of the [tortoise] deity 神明, the snakes' harm was averted and the entire south forever rid of their poisonous influences.

The special significance of turtles as conveyors of portents is the subject of two separate chapters in the Record of Marvels. It was linked to their ancient connection with divination, as illustrated in the following story: ${ }^{164}$

The local inhabitants at Mount Xiliang 西梁山 in Xuanzhou 宣州 (modern Xuancheng, Anhui) catch turtles for a trade. They prize the shell off the live animal to make the material used for divination by burning 灼卜 (i.e., applying heat to the plastron). ${ }^{165}$ When they have separated the shell from the meat, they discard the remains into the water. Sometimes these still move. Some say they grow their

TG 463.3815; cf. below), about the apparition of three strange birds to mark the construction of a temple.

162 LJ 5.4a-5a; ap. TG 472.3888-89.

163 Cf. the vengeance of “The little snake of Pixian 師縣小蛇” (LJ 5.8a-b and above). In “Cui Daoji 崔道紀” (LJ 5.9a; ap. TG 133.948), Cui's servant catches a fish swimming at the surface of a well and uses it to prepare a broth for his master. Thereupon a yellow-robed envoy 花使者 descends from heaven, seizes Daoji, and announces: "Mere mortal of the world below, how dare you kill a dragon child! As an official you ought to have reached the rank of chief minister. As for longevity, you should have attained seventy years. Now you deserve to be cut short." Daoji, aged thirty-five, dies a sudden death the same night.

164 LJ $5.5 b$.

165 See Sarah Allan, The shape of the turtle: Myth, art, and cosmos in early China, 112-23, Albany: State University of New York Press, 1991. 
shells again. Year after year a daily provision of unknown limit 不知紀極 ${ }^{166}$ is obtained, yet the supply of turtles produced by this mountain is never exhausted. All the turtles used in the world for divination come from there.

Before Xuanzong, the founding emperors of the Tang had already been favored by tortoise omens. In "The stone tortoise of Gaozu 高祖石龜," 167 the Record tells the story of Lord Lao's apparition in 620, the third year of Gaozu's reign. The prince of Qin 秦王 (Li Shimin), the son of Gaozu and future emperor Taizong, orders the witness Ji Shanxing 吉善行 to submit a memorial. But Shanxing reports back to Lord Lao: “To make a presentation at the capital without supporting evidence is very difficult." Lord Lao replies: "On the day you enter the capital there shall be a tribute offering of a stone tortoise as evidence." When he arrived at the court, a stone tortoise 石龜 (i.e. a stone in the shape of a tortoise) was indeed presented as tribute from Shaozhou 邵州 (modern Yuanqu, Shanxi). Underneath it had six characters: "Peace in the empire for a thousand times ten thousand days." 168

Taizong's own reign (626-649) was similarly blessed: In 626, when emperor Taizong had "pacified the interior disturbances," a white tortoise 白黽 was discovered wandering about on the lotus leaves in the pond of the imperial park 石苑中. ${ }^{169}$ When Taizong caught it, it changed into a white stone with the pure luster of jade. After he had assumed power, the emperor issued a charter, saying: "High Heaven protects me. It has bestowed a sacred tortoise on me."

These antecedents upheld the significance of a series of similar portents in Wang Jian's favor. For the year of the foundation of the Shu kingdom, the Record of Marvels

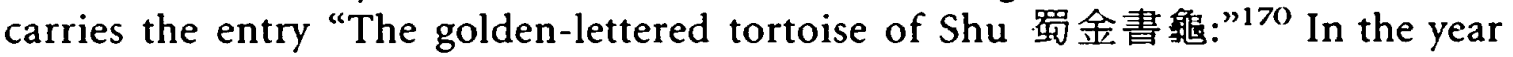
dingmao丁卯 in Shu (907), ${ }^{171}$ a tortoise engendered four tortoises in a cave in the embankment of the city moat at the Huichang temple 會昌廟. Each measured two or three inches and all had in golden writing the characters for "king" and "great good fortune" on their backs. ${ }^{172}$

166 A classical expression found, among others, in the Yijing, Shangshu, and Zuozhuan.

167 LJ 5.5b-6a; ap. TG 135.970.

168 On this episode, see also Du Guangting's Lidai chongdao ji 歷代崇道記（885）4a-5a, D 329, no. 593 and Verellen, "A forgotten restoration," 122-23.

169 LJ 5.6a; ap. TG 472.3887. For an earlier example, see “Tortoise Embankment 鼠塘” (LJ 5.6a-b): In the first year of Taishi ( sic) under the Eastern Jin (317-420), a gleaming white spirit tortoise emerged from the water and wandered about on top of the embankment. It was thus named Tortoise Embankment. Below, there were over one thousand qing of fertile land. For the link between a “Tortoise Embankment" and irrigation, cf. Song shi 宋文 173.4183 .

170 LJ 5.6a.

171 Year of the official foundation of the Great Shu Empire and of Wang Jian's "personal destiny 体命," i.e. the return of his birthyear (dingmao 847) after a full cycle of sixty.

172 In his preface, Du Guangting refers to the Yellow River Chart and Luo River Writing among "texts that set forth incidences of the divine transformations between Yin and Yang, 
Three years later, there appeared the "Golden tortoise of Xihu 西湖金龜:"173 On the fifth day of the sixth month of Wucheng 3 (910), the governor 太守 Meng Yanhui 孟彥 暉 ${ }^{174}$ of Guanghan 廣漢 (north of Chengdu, near the archaeological site Sanxingdui) memorialized the throne as follows: "West Lake 西湖 has a golden tortoise one inch in diameter. It wanders about on top of the lotus leaves. [I submit] an illustration to make it known." 175

“The white tortoise of the emperor of Shu 蜀黃帝白黽:" ${ }^{176}$ On the fifteenth day of the seventh month of Qiande 1 (the Zhongyuan festival of 13 August 919 and) birthday (of the second emperor of Shu, Wang Yan, r. 918-925), ${ }^{177}$ the garrison commander 鎮 將 at Pengkou 堋口 (Guanxian), Wang Yanhui 王彥徽, found a white tortoise in the temple of the Perfected Luo 羅真人宮 (Luo Gongyuan; see above).

In addition to tortoise miracles, apparitions of dragons, the imperial symbol, also played a role in the legitimation of the Shu kingdom:

In the gengwu 联午 year (910-911) under the Shu, ${ }^{178}$ the prefect of Jinzhou 金州 (modern Ankang), Wang Zonglang 王宗郎, ${ }^{179}$ memorialized the throne: “In Xunyang county 洵陽縣, on the banks of the river Xunshui 洵水 (now Xunhe 洵河, an affluent of the Hanshui at Xunyang, northeast of Ankang), stands the Black Smoke temple 青煙廟. For several days a cloud of smoke darkened the sky above the temple. Music was heard day and night. Suddenly one morning the water broke into ripples and a flock of dragons emerged above the water. They move into the river Han 漢江... Large and small, some fifty of them, in all shapes, traveling in formation, piled into the Han. Then, returning to the site of the temple, they traveled back and forth several $l i$. They remained for three days, sometimes hidden, sometimes in view."

In the guiyou 癸西 year (913-914), a small dragon was found in the fields in Xipu 㸝浦 (county west of Chengdu). Blue-black in color, it had been cut in two. ${ }^{180}$ After ten

and talismanic writings that portend good and evil fortune," alluding to the myth that Chinese writing emerged from the markings on the shell of a turtle. See John Henderson, The development and decline of Chinese cosmology, 82-87, New York: Columbia University Press, 1984.

173 LJ 5.5a; ap. TG 472.3886.

174 Meng was also a patron of Du Guangting's liturgical services; see Guangcheng ji 廣成集, the remaining fragment of Du's collected works, 8.5b-6a, D 337, no 616.

175 For this incident, see also Shiguo chunqiu 36.511.

176 LJ 5.6 .

177 Cf. Guangcheng ji 2.2a-b.

178 LJ 5.2b; ap. TG 425.3457; Shuofu 118.4b.

179 I.e. Quan Shilang 全師朗, an adopted son of Wang Jian; cf. Klaus-Peter Tietze, Ssuch'uan vom 7. bis 10. Jahrhundert, 222, Wiesbaden: Franz Steiner Verlag, 1980.

180 LJ 5.2b-3a; ap. TG 425.3457. The event signaled the defeat and death of the rebellious crown prince Yuanying; see below. 
days it stank of putrefaction... On the west side of the great hall by Lake Moho chi 摩訶 池 (i.e. the Great Dragon, mahäkumbhira, Lake in Chengdu), ${ }^{181}$ there is also a dragon well. It is very numinous, and people dare not desecrate it... At the Chengyan temple 乘 煙觀 south of the Wuhou residence 武侯宅 ${ }^{182}$ in Shutai ward 書臺坊, Chengdu, there is a Dragon Well 龍井. ${ }^{183}$ In the ancient well, fishes six or seven cun long swim about at the surface of the water.

Like the Shu tortoises, the inscribed bronze tablet or “oracle text 瑞文” left behind by the immortal Zhang Hongdao 章弘道 during the Tianbao era (741-756) to announce the accession of the Wang family in $907,{ }^{184}$ had its counterpart in an "oracle stone text 瑞石文"185 bestowed on the Tang founder Gaozu: When Li Xiyu 李襲譽, a provincial official under Gaozu, ${ }^{186}$ was prefect of Liangzhou 涼州 (Gansu), he reported that in Changsong 昌松 (Liangzhou) an oracle stone had spontaneously formed written characters announcing the ascendancy of the Li family of Tang rulers.

Among the Tang antecedents adduced in the Record of Marvels in support of its legitimation of the Shu regime belongs a further group of stories describing events connected with the exile of emperor Xizong in Sichuan (881-885). The author of the Record was himself a participant in these events which helped establish the region and its capital Chengdu as a base fit to sustain an imperial court: ${ }^{187}$ Wang Zao 王慥, ${ }^{188}$ a Xizong loyalist who had served the court in exile at Chengdu, was sent with an advance party to Chang'an to prepare the return of the court to the capital in 885 . After the emperor's second forced departure in 886 , Wang Zao fell into enemy hands. Declining to collaborate with the rebels on the grounds of illness, he died of chagrin. The heroic death of a group of Xizong loyalists, artisan Liu Wanyu 劉萬餘 et al., prevailed upon to collaborate with the rebel Huang Chao 黃巢 in occupied Chang'an, is the subject of a long narrative in the same chapter devoted to "Loyalty." 189 Next to such paragons of Loyalty, saints of Filiality like Julong hongdao 句龍弘道 (see above) also bore witness to the notion that the Confucian moral order remained intact and stood by the emperor, at a time when Xizong's political legitimacy was in serious doubt.

At this desperate juncture, the apparition of General Li 李將軍, the deified early Tang military hero Li Jing 李靖 with his spirit troops 陰兵 to welcome emperor

181 See Chengdu chengfang guji kao, 350.

182 The shrine of Zhuge Liang 諸莴克 (181-234); see Chengdu chengfang guji kao, 344-47.

183 LJ 5.3a; ap. TG 425.3458; Shuofu 118.4b-5a.

184 See "Strange crows at Mount Xianju 仙居山異鳥" (LJ ap. TG 463.3815), mentioned above, and Guangcheng ji 4.11b-12a, Xin Wudai shi 63.789. The immortal was rewarded with an enfeoffment by Wang Jian the same year. See Verellen, "Liturgy and sovereignty," 63.

185 LJ 7.7b-8a; ap. TG 398.3186

186 See his biographies in Jiu Tang shu 59.2331-32 and Xin Tang shu 91.3790-91.

187 See Verellen, $D u$ Guangting, 65-100, and "A forgotten restoration."

188 LJ 3.2b-3a; discussed in Du Guangting, 108.

189 LJ 3.3a-4b; translated in Du Guangting, 81-84. 
Xizong on his "tour of inspection" in Shu in 881, signaled supernatural aid for the beleaguered sovereign. ${ }^{190}$ Under the last-but-one Tang emperor, Zhaozong (888-904), a miraculous apparition of supernatural snakes at the Shenxian relay station 神仙驛 (Hejiang, Sichuan) announced the defeat of the rebellious military governor of Shannan, Yang Shouliang 陽守亮, in $894 .^{191}$

Another military portent, though not precisely dated, is probably set in the early days of the Former Shu kingdom: Zheng Junxiong 鄭君雄 ${ }^{192}$ was prefect of Suizhou 遂 州 (modern Suining). One evening he discovered several thousand troops and standard-bearers on the dike on the east side of the river (Suizhou was situated on the west bank of the river Fujiang 涪江). The encampment with its pennants, tents, and the clamor of men was no different from that of an army on campaign. Zheng gave an alert within the prefecture and, under cover of night, sent a scout to spy out the situation. The great army had already departed. Only a handful of men remained behind. To the scout's inquiry they answered: "We are river spirits. For some years now, there have been disturbances in the river prefectures 川府 and we were moved into the [Yangzi] gorges. Now that peace is restored far and near, we are returning to the river." The emissary looked around: There were traces of a camp and of burnt tents. Everything could be verified.

The divine power of a legitimate ruler extended downward to the localities through the investiture of his local officials. The prominent role of county magistrates in the often conflictual relations between the state and local cults is an expression of this principle. The Record of Marvels also depicts local officials as subjects of miraculous occurrences. Magistrate Cui 崔令, haunted by the god of Bishan 壁山神, and the court diviner Ma Chuqian 馬處謙, disciple of the adept Hu Tian 胡恬 (see above), belong in this category.

Officials redeemed by healing miracles are grouped in the Luyi ji under "marvelous responses 感應:" Zhu Bo 朱播, ${ }^{193}$ magistrate of Jiajiang 夾江, Jiazhou 嘉州 (modern Leshan), and acting Minister of Works 工部尚書, fell ill while in office. He was unable to move his limbs and his body grew heavy. To turn over, he required the support of several people. He was thought to be the victim of a possession and medicines were of no avail. In a half-sleep, Zhu saw seven immortals seated in a row in front of him. A voice said: "These are immortals, there is nothing they can't do..." Then the vision disappeared. Gradually, Zhu got better and resumed his official duties. He had been healed by the seven Perfected of the Northern Dipper 北斗.

In the year Yongping 3 (913) in Shu, the executive officer and right vice-president

190 LJ 3.8a; Du Guangting, pp. 85-86.

191 LJ 5.7a-b. The date Qianfu 乾符 in this text, corresponding to the period 874-879, is an error for Qianning 乾察 (894-898). Yang was executed in 894; see Zizhi tongjian 259.8457.

192 LJ 4.4a-b; ap. TG 313.2477-78. On Zheng, see also Guangcheng ji 10.13a-15a.

193 LJ 3.6a-b. 
of the Department of State Affairs 判官右僕射 Yin Xiang 尹瓖 ${ }^{194}$ took to bed with similar symptoms as $\mathrm{Zhu}$ Bo. In the end he had a vision of an old man with white moustaches and temples, wearing a white robe (one of the iconographies of Lord Lao), who said to him: "Your illness is already cured. Why don't you rise forthwith?" And so he did, completely healed, to the amazement of the entire family.

Some magistrates were themselves reputed immortals and said to have "disappeared" at the end of their careers:

Yuan Qi 袁起 ${ }^{195}$ was a native of Xiangzhong 湘中 (Hunan) at the time of the Later Han ( $A D$ 25-220). Once he suddenly became inebriated for three days in his village. When he came to, his vomit smelled of wine. Qi declared that he had been banqueting with heavenly spirits 天神. Later, when serving as magistrate of Hanyang 漢陽 (modern Qingfu, Sichuan), he accurately foretold lean and prosperous harvests. By daytime he adjudicated matters of this world 陽, by night of the underworld 陰. Eventually, he mounted a cloud and ascended into heaven. His whereabouts are unknown.

Liu Zihua 柳子華 was magistrate of Chengdu under the Tang [emperor Daizong, r. 763-779]. ${ }^{196}$ One day at high noon an oxcart arrived with women riding before and after it. They made directly for the magistrate's hall and entered. A servant was sent to announce to Liu: "The dragon lady 龍女 has arrived." Presently she descended from the cart and was helped up the steps by her attendants. Facing Zihua, she said: "It is predestined 宿命 that we shall be husband and wife, sir. That is why I have come." He ordered wine and music and there was great rejoicing. When the wedding rites had been completed, she left. From then on she came and went regularly. This was widely known. Zihua resigned his office. It is not known where he went, but popular tradition has it that he entered the dragon palace 龍宮 and became a water immortal.

The grandson of Zihua, Liu Junqing 柳君慶, ${ }^{197}$ was administrator of the governor's guard 節度押衙 and security officer 鎮遏使 at Qingcheng 青城 during the Qianfu era (874-880). Devoted to good works and spiritual values, he cured the ills of the poor with medicine and acupuncture and cared indefatigably for soldiers and commoners. He was courteous and just, stood for sincerity and veracity, and was highly esteemed by his contemporaries. Junqing owned a precious pearl, the size of a ball. He said it was a treasure handed down by his ancestors who had kept it for several generations. It reflected objects in faithful detail, but upside down. When the local markets 草市 of Qingcheng were attacked by bandits, Liu, as gar-

194 LJ 3.6b-7a.

195 LJ 2.2a-b; ap. Shuofu 118.2b-3a.

196 LJ 5.1 a-b; ap. TG 424.3450-51. According to Jiu Tang shu 165.4312-13 and Xin Tang shu 163.5031, Liu had foreknowledge of his death and composed his own tomb inscription.

197 LJ 5.1b-2a. 
rison commander, led out his troops to the rescue of the Taoba garrison 陶壩鎮. Surrounded by the bandits..., he bravely fought to the end and was killed. Far and near all grieved for him.

The opening entry of the Record of Marvels, “The Demon Valley Master 鬼谷先 生,"198 tells the story of the Perfected immortal of antiquity Wang Xu 王詡, surnamed the Master of Demon Valley (Guigu), and of his disciples, the statesmen Zhang Yi 張儀 (d. 309 BC) and Su Qin 蘇秦 (d. 317 BC). ${ }^{199}$ Guigu lived from the time of Xuanyuan 軒轅, the Yellow Emperor, through the Shang and Zhou periods, then followed Lord Lao on his journey to convert the Western regions 流沙, and finally returned to the Middle Kingdoms at the end of the Zhou to settle at Demon Valley Mountain 鬼谷山 on the banks of the Han 漢 river (i.e. in Hanzhong 漢中, the border region between modern Shaanxi and Sichuan). In the episode of Guigu's legend related in the Record of Marvels, the master persuades Zhang Yi and Su Qin by means of parables from the Zhuangzi to retire from government service and the diplomatic rhetoric of the Warring States period known as the "art of the horizontal and vertical alliances 縱橫之術."

What may have prompted Du Guangting to place this story at the head of his collection of Marvels? The text itself offers no explicit answer to this question, but an implicit rapport with the Shu region suggests itself on several levels: Hanzhong was a place rich in memories of the cultural and religious history of the region, recalling especially the civilization of the Ba people and the rise of Heavenly Master Taoism; ${ }^{200}$ Zhang Yi had been a leading figure in the Qin conquest and early administration of Shu in $316 \mathrm{BC},{ }^{201}$ and he is credited with the construction of the first city wall of ancient Chengdu, ${ }^{202}$ most importantly, perhaps, Du Guangting had decreed Wang Xu an ancestor of Wang Jian by installing him among the gallery of "Wang-lineage immortals," Wangshi shenxian zhuan 王氏神仙傳, a hagiographic cum genealogical collection compiled in honor of his sovereign. ${ }^{203}$

The choice of the source for the Luyi ji's narrative concerning the Lord of Lin and the origin of the $\mathrm{Ba}$ people, translated above, was also implicitly significant.

198 LJ 1.1a-2a; ap. Tushu jicheng 㽤書集成 507.36a (ce 225, vol. 94). Cf. Guiguzi 鬿谷子, D 671, no. 1025, and Xiao Dengfu 硐登褔, Guigu zi yanjiu 魅谷子研究, Taipei: Wenjin chuban she, 1984.

199 See Shiji 70.2279-305 and 69.2241-77.

200 Chapter 2 of the Huayang guo zhi is devoted to Hanzhong, placed between the chapters on $\mathrm{Ba}$ and on Shu. On the Heavenly Master movement under Zhang Lu 張㬗 in Hanzhong, see Howard L. Goodman, "Celestial Master Taoism and the founding of the Ts'ao-Wei dynasty," Asia Major 3rd ser. 7.1 (1994): 5-33.

201 See Huayang guo zhi jiaobu tuzhu, 128, and Sage, Ancient Sichuan, 112-15.

202 See Huayang guo zhi jiaobu tuzhu, ibid., and Chengdu chengfang guji kao, 15-22.

203 See the reconstruction by Yan Yiping 雄一萍 in his Daojiao yanjiu ziliao 道教研究資料, 1:3.2-4, Taipei: Yiwen yinshu guan, 1974. On the background to this work, see Verellen, $D u$ Guangting, 179-80. 
Transcribing the text from the History of the Jin (see note 28 above) where it appears as part of the biography of $\mathrm{Li} \mathrm{Te}$ 李特 (d. AD 303), Du Guangting includes a paraphrase of the opening line of that text: "Li Te, zi Xuanxiu 玄休, was a descendant of the Lord of Lin." The author says no more about $\mathrm{Li} \mathrm{Te}$, but the reference evokes another episode in Shu's history of political and religious autonomy. $\mathrm{Li} \mathrm{Te}$, the descendent of the Lord of Lin, was himself the ancestor of an independent ruling house in the region. His son $\mathrm{Li}$ Xiong 李雄 (274-334) founded the Sixteen Kingdoms state successively known as Cheng 成 (304-338) and Han 漢 (338-347). ${ }^{204}$ The Li family had been aided in its conquest by the Taoist master of Mount Qingcheng 青城山, Fan Changsheng 笵長生 (d. 318). A true heir to the ancient Heavenly Master movement in Sichuan, Fan controlled a small church-state which contributed material support to Li Xiong's military campaign. In return, Fan Changsheng was appointed chancellor and granted the titles Worthy 賢 and Grand Master of Heaven and Earth 天地太師 by the newly established kingdom. ${ }^{205}$ Fan Changsheng's politico-religious role provided a direct model for Du Guangting's own activities as Taoist master of Mt. Qingcheng and as minister at the court of Shu six hundred years later.

Four years after the Shu territory under the Cheng-Han kingdoms had been recaptured by the Eastern Jin, a Tibetan named Fu Jian 苻健 established the kingdom of Qin 秦 (351-394) in Guanzhong, ${ }^{206}$ the southern part of which overlapped with the northern territory of the late Cheng-Han state in Hanzhong. The Luyi ji comments on these events as follows: ${ }^{207}$

When the Fu 符 (i.e. 苻) family first established themselves as rulers of Guanzhong, a giant 長人 appeared at Xinping 新平 (modern Binxian). He spoke to a commoner named Zhang Jing 張靖, saying: “The Fu family accords with Heaven and has received the mandate. From now on a period of Great Peace will reign. Those outside shall return to the center (i.e. Guanzhong) and enjoy prosperity and security." Zhang asked [the giant's] name but the latter did not reply. Suddenly he vanished. The magistrate of Xinping reported the incident to Fu Jian. But Fu, suspecting a case of fraudulent sorcery, had Zhang thrown into prison.

At that moment a torrential downpour set in and caused the Yellow and Wei Rivers [to flood] ${ }^{208}$ the Pujin 蒲津 ford (at present Puzhou). The inspector Kou

204 See Kleeman, Great Perfection.

205 See Huayang guo zhi jiaobu tuzhu 9.483-85; Jin shu 58.1583, 120.3022-30, 121.3035-40; and Anna Seidel, "The image of the perfect ruler," History of Religions 9 (1970): 233-34.

206 See Michael C. Rogers, The chronicle of Fu Chien: A case of exemplar history, Berkeley: University of California Press, 1968.

$207 \mathrm{LJ} 2.10 \mathrm{~b}$. This episode also features in the biography of Fu Jian in Jin shu 112.2871. For another Taoist legend connected with the Fu-kingdom reported by Du, see the story "Li Ban 李班” in his Shenxian ganyu zhuan 2.9b-10a, commented in Verellen, "The Beyond within," 267 n. 6.

208 Jin shu variant. 
Deng 寇登 found a shoe in the Yellow River which measured seven feet and three inches in length. There were human footprints to match it, with toes more than one foot long and skin markings one inch deep. Fu Jian sighed and said: "Between Heaven and Earth, what doesn't exist? Zhang's vision had indeed been no illusion." And he was pardoned.

On the occasion of the flooding of the river Min 峔江 in 910, three years into the reign of Wang Jian as emperor of Great Shu, Li Bing 李冰, the Warring States hydraulic engineer and chief deity of water management in the Chengdu plain, made an appearance that saved the kingdom from a natural disaster. In the summer of that year, reports the Record of Marvels, ${ }^{209}$ when the floodwaters threatened the Chengdu plain, the shouts of thousands of men where heard in the night on the great dam at Guankou 灌口, the site of Li Bing's original hydraulic works. Rows of countless torches, impervious to the rain and wind, lit up the scene. At dawn, the great dike was found displaced by several hundred yards, ${ }^{210}$ diverting the flood waters into the river Xinjin 新津江. The flags that had been placed inside the Li Bing temple 李冰祠 ${ }^{211}$ were all drenched. As a result of the diversion, the Chengdu plain was spared.

Four years later, in 914, numerous supernatural manifestations occurred to confirm the legitimacy of the Wang Jian regime in Shu. According to the Record of Marvels, on the fourth day of the fifth month in the year Guanghua 2 (899), when the Shenwu Emperor 神武皇帝 (i.e. Wang Jian) ${ }^{212}$ was “biding his time," the entrance of the Magu grotto 麻姑洞 (see above) had opened spontaneously after a landslide. The county official and prefect of Shikang district 時康鄉, Taoist Yang Jing 楊靖, Zhang Shouzhen 張守真, and others, reported the matter up to the prefecture in a memorial complete with illustrations and detailed descriptions of the entrances, caverns, paths, and interior of the grotto. According to the district registers 鄉帳, the cavern had been named Fanyang in the past (in reference to the Heavenly Master diocese; see above):

Originally, it had for the most part been closed. During Yuanhe (806-821) [sic], when the prince of Nankang 南康王 Wei Gao 韋幂 (d. 805) assumed office in

${ }^{209}$ LJ 4.4a. See the translation in Verellen, Du Guangting, 158. The incident was also the subject of a congratulatory memorial to the throne by the same author; see "He jiangshen yiyan jian 賀江神移殹嵟” (910) in Chengdu wenlei 成都文類 (1200), compiled by Yuan Yueyou 袁説友, 18.21b-22a, in Yingyin Wenyuan ge siku quanshu, vol. 1354.

210 Archaeologists date a major change in the disposition of the main dam and the spillover dam to this period; see Zhang Xunliao 張县燎, “Li Bing zao Lidui di weizhi he Bao-

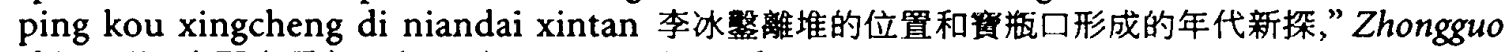
shi yanjiu 中國史研究 4 (1982): 87-101, citing the present account in Luyi ji.

211 A major Taoist and regional sanctuary to this day; see Ding Ruomu 丁若木, “Dujiang yan shenci yu daojiao 都汀.垵神祠與道教,"Zongjiao xue yanjiu 宗教學研究 1994.4, 24-31.

212 By his posthumous title, see Shiguo chunqiu 36.529. 
$\mathrm{Shu}^{213}$ the grotto suddenly opened. At the time it was said: "When the grotto entrance opens, harvests will be plentiful and goods inexpensive." Suddenly it closed again, up to the present time. After it reopened, there was indeed great prosperity everywhere. The grotto's original name is Magu dong; next to the mountain are the foundations of Magu's residence. Thus it is a place of Taoist worship. 214

The apparition of immortals at the Yangmo grotto 楊謨洞 in 914 was reciprocated by an imperial enfeoffment of the immortals and a series of commemorative changes of place names the same year: ${ }^{215}$

Synopsis: In the jiaxu 甲戌 year of Yongping 永平 4 (914), the prefect of Lizhou 利州 (modern Guangyuan), Wang Chengshang 王承賞, ${ }^{216}$ memorialized that in the inaccessible Yangmo grotto of Mount Daochang 道長山, twenty li into the mountains west of Shendu 深度, reputed to be the dwelling of immortals, recent apparitions had been reported by many witnesses. The master of Taoist ritual 道門威儀, Grand Master of Accomplished Perfection 凝真大師, and others, were ordered to present a Green Petition 青詞 ${ }^{217}$ and an imperial gift of incense 御香. With the palace commissioner Yang Zhishu 楊知淑 they proceeded to make a jiao 醮-Offering of Thanksgiving. The immortals appeared as before. Thereupon the renaming of Jinggu xian 景谷縣 as Golden Immortal county (Jinxian xian 金仙縣) and of Daochang shan as Mt. Mysterious Capital (Xuandu shan 玄都山) was proclaimed, while the Yangmo dong became the Purple Cloud or Dwelling of Immortals Grotto (Zixia dong 紫霞洞). The presiding deity of Mt. Xuandu was enfeoffed as duke of Yuqing 玉清公, and the Purple Cloud Temple (Zixia guan 紫 霞觀) was established in official recognition of these events.

The Record of Marvels gives no explicit clue as to the significance of the timing of these accumulated portents in the year 914 . The historical context, however, makes it quite clear: In August 913, the designated crown prince of Shu, Yuanying 元膺, had

213 The reign name Yuanhe is mistaken: The celebrated local administrator (see his biographies in Jiu Tang shu 140.3821-26 and Xin Tang shu 158.4933-37), revered among other things as an incarnation of Zhuge Liang, died in 805; he served as governor of Jiannan West during 785-805. On his role as defender of the Southwest, see Charles Backus, The Nan-chao kingdom and T'ang China's southwestern frontier, 90-94, Cambridge: Cambridge University Press, 1981.

214 LJ 6.2b-4a. For the same author's version of the legend of the immortal lady Magu, see Yongcheng jixian lu 䓶城集仙錄 (betw. 913-933), 4.10b-13a, D 560-61, no. 783.

215 LJ 1.5b-6a; see Verellen, "Liturgy and sovereignty," 63-64.

216 The name indicates that he was an adopted grandson of Wang Jian.

217 Written supplications provided by the court for use in local rituals; see "Liturgy and sovereignty," 69-70. 
unsuccessfully mounted a coup d'état against his father (see n. 180). After the defeat and death of Yuanying, Wang Jian's youngest son Zongyan 宗衍 (899-926) was installed as crown prince in the tenth month of 913. As advisor to Wang Jian and tutor to Yuanying, Du Guangting had been a close witness of these events, which had constituted the most serious dynastic crisis in the short history of the Former Shu kingdom. The months following the dynastic restoration were characteristically marked by portents of the continued legitimacy of the reigning house. ${ }^{218}$

Two further crises in the final years of the first reign of the Shu kingdom are documented in the Record of Marvels: The palace fire of 915 , confirmed in 1943 by a major archaeological discovery, ${ }^{219}$ and the death of the founding emperor Wang Jian, in 918. Both of these ill-starred events had been the subjects of oracles reluctantly imparted by the court diviner Huang Wanyou 黃萬祐 and recorded in the Luyi ji. ${ }^{220}$ Elsewhere the Record relates that [Wang] Zongkui 宗獎, the adopted son of Wang Jian, ${ }^{221}$ died in the same year as the emperor of Shu. In the year Guangtian wuyin 戊寅 (918), he had dreamt three times of a steelyard 秤 of ten thousand pounds, suspended from the crossbeam supporting the ridge of the roof on his home. Suddenly the beam and steelyard both snapped. Zongkui (and Wang Jian) died the same year.

Once Wang Jian's military conquest of Shu had been consolidated, the gods and immortals of Shu turned their attention to the economic prosperity of the new kingdom, providing evidence of its legitimacy in that vital domain. The disclosure of the entrance to the Magu grotto was interpreted, as mentioned, as an augury of abundant harvests; and the rediscovery of the ancient Yanyang grotto 焰陽洞 under the second rcign of the Shu kingdom, in 921, put a major traditional source of economic prosperity at the king's disposal:

According to ancient tradition, the Yanyang grotto 焰陽洞 ${ }^{222}$ was situated on Yangshan 陽山 in Lingzhou 陵州 (modern Renshou). It had been concealed and its exact location forgotten until, at midnight on the sixteenth day of the first month of the third year of Qiande (26 February 921), the commissioner of well inspection 井監使 and senior tutor to the heir apparent 太保 Ma Quanzhang 馬全章 had a dream vision of a Taoist in a purple robe and high cap who led him to a steep cliff and said: "This is the Yanyang grotto. For many years it has been blocked. If you can develop and manage it, it

218 See Verellen, Du Guangting, 162-68, on the Yuanying crisis and its aftermath, and "A forgotten restoration" on the ideological and theological stakes in rebellion and dynastic restoration.

219 See Du Guangting, 169.

$220 \mathrm{LJ}$ ap. TG 86.558 and Leishuo 8.26b-17a. This item has not come down via the Daozang edition. The TG transmission has the alternate attribution to Yeren xianhua 野人閒話, the work of Du Guangting's contemporary Geng Huan 耿煥 (preface dated 921), which survives only in citation fragments. On Huang's oracles concerning the reigning house of Shu, see $D u$ Guangting, 168-69.

221 LJ 3.7b. For Zongkui's relationship with Wang Jian, see Shiguo chunqiu 39.583.

222 LJ 6.7b-9a; ap. Shiguo chunqiu 37.536-7; Tangwen shiyi 50.24a. 
should be of benefit to the realm." And he indicated a small opening, which Quanzhang was able to recover and have excavated the following day.

The grotto was situated directly above a brine source 骽泉 which had been a major contributor to the wealth for the region since antiquity. Its original creation or discovery had been variously attributed to Li Bing and Zhang Daoling, both gods and culture heroes of the region. ${ }^{223}$ The immortal's words at the time of the auspicious rediscovery - "It should be of benefit to the realm" - recall the deeds of these early benefactors and vindicate the Wang kingdom as an heir to the mythical traditions of ancient Shu.

The words of an unusually explicit endorsement of the Wang regime in Shu, which I have discussed elsewhere together with its elaborate authenticating context, ${ }^{224}$ encapsulate the memory of the fashioning of the land of Shu by the saints and heroes of its prehistory. It specifically evokes the transformative labors of a long series of regional gods, mythical kings, and culture heroes, including the Turtle Spirit King Bieling 鱉䠤 - the Yu the Great of Shu, the Five Strong Men 五丁 (note 91 above), Li Bing, and Zhang Daoling, who leveled mountains, filled valleys, breached impasses, opened natural resources, and established communications between isolated communities. ${ }^{225}$ This endorsement, in the form of a prophecy uttered by a local immortal at the site of the Heavenly Master diocese Houcheng 後城 (Shifang), ${ }^{226}$ was conveyed to the polity of Shu by a guard officer named Huang Qi 黃齊, who counted among Du Guangting's liturgical patrons and was probably his immediate informant: ${ }^{227}$

The mountains and rivers of Shu constitute a land of great blessings 蜀之山 川是大褔之地. It has long been fit to serve emperors and princes as capital. Many are the sages and worthies of preceding generations who for the sake of posterity established control over its hills and waters and breached its impasses with arteries of communications. I am familiar with every corner of this land...

223 See the translation of this story and a discussion of its context in the mythology related to salt production in early Sichuan in Verellen, "Zhang Ling and the Linging salt well," 252-55.

224 L) 2.6a-b; ap. TG 86.599; "Liturgy and sovereignty," 74-76.

22.5 See Li Cheng 李誠, Ba Shu shenhua chuanshuo chulun 巴蜀神話傅説弨論，Chengdu: Dianzi keji daxue chuban she, 1996, and Verellen, "Zhang Ling and the Lingjing salt well," especially pp. 264-65.

226 See Wang Chunwu, Tianshi dao ershisi zhi kao, 243-53.

227 See Guangcheng ji 4.12b-13b for Du's supplication written for a mourning ritual sponsored by Huang. This is not the only story in the Record of Marvels for which a contemporary informant is named or implied: See “Collator Su 蘇校皆” (LJ 1.6b-7a), “Lord Xu 許君” (LJ 1.7a-b), “Ren Sanlang 任三郎” (LJ 2.5a-6a), “Zheng He 鄚鹤” (LJ 2.7b), “Li Deyu 李德裕” (LJ 2.7b-8a), “Scholar Cui 崔生” (LJ 4.1a-3a), “Magistrate Cui 崔令” (LJ 4.7b-9a), “Liu Junqing 柳君屡” (LJ 5.1b-2a), “The Dragon Well of Liu Wen 劉文龍井” (LJ 5.2a-b), “The Xunyang dragons 洵陽龍” (LJ 5.2b), “The Xipu dragon 犀浦龍” (LJ 5.2b-3a), “Mao Yihuan 毛 意歡” (LJ 6.5b-7a), and “Tomb robbers smitten by dementia 墓賊發狂” (LJ 8.6a-b). 
Now if you removed [the element signifying] “insect 蟲” from the character for "Shu 蜀” and wrote "metal 金” [in its place], then that would correspond appropriately to "Metal Virtue 金德."228 [Wang Jian and his descendants] will rule in perpetuity as kings over this western region, and all the world shall bow to them. You should announce this for me.

Huang Qi did attempt to communicate this evidence of the Shu regime's legitimate succession to the Tang but, according to Du Guangting, "was to the end unable to gain access to the leadership 終無申遠之路." 229 Huang himself died within months of the revelation - having bequeathed his story to the kingdom's foremost disseminator of marvels.

228 Glyphomancy and Five Phase theory, two favorite disciplines of Chinese legitimation lore, combine here to affirm Shu's possession of Metal Virtue, which "naturally" succeeded the Earth Virtue of the Tang.

229 His difficulty recalls Ji Shanxing's reluctance to report the apparition of Lord Lao to Gaozu, Zhang Jing's punishment for his pains on behalf of Fu Jian, and many other examples of the same authenticating device. 